\title{
The first geological record of a palaeotsunami on the southern coast of the Baltic Sea, Poland
}

\author{
Karol ROTNICKI ${ }^{1,2, ~ *, ~ J o a n n a ~ R O T N I C K A ~}{ }^{3}$, Tomasz GOSLAR ${ }^{4,5}$ \\ and Brygida WAWRZYNIAK-WYDROWSKA ${ }^{1}$
}

\footnotetext{
1 University of Szczecin, Institute of Marine and Coastal Sciences, Aleje Mickiewicza 18, 70-383 Szczecin, Poland

2 Adam Mickiewicz University, Institute of Geoecology and Geoinformation, Dzięgielowa 27, 61-680 Poznań, Poland

3 Adam Mickiewicz University, Institute of Geology, Maków Polnych 16, 61-606 Poznań, Poland

4 Adam Mickiewicz University, Faculty of Physics, Umultowska 85, 61-614, Poznań, Poland

5 Poznań Radiocarbon Laboratory, Rubie 46, 61-612, Poznań, Poland
}

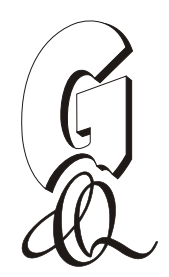

Rotnicki, K., Rotnicka, J., Goslar, T., Wawrzyniak-Wydrowska, B., 2016. The first geological record of a palaeotsunami on the southern coast of the Baltic Sea, Poland. Geological Quarterly, 60 (2): 417-440, doi: 10.7306/gq.1294

\begin{abstract}
Tsunami deposits have not previously been recorded along the southern coast of the Baltic Sea. The results of present research provide evidence of high-energy event layers that occur on the bottom of two hemispherical hollows cut into glaciolimnic silt and glaciofluvial sand and gravel of Late Weichselian age. The event deposits are represented by poorly sorted marine sand with admixtures of pebbles and allochthonous biogenic detritus: marine, brackish and occasionally freshwater shells and shell debris of bivalves and snails, plant macrofossils from the nearshore zone, shreds and lumps of peaty material, gyttja and organogenic silt, lumps of charcoal, wood pieces and tree branches and trunks. All these features are commonly considered indicative of tsunamis. The age of the biogenic detritus found in the tsunami layer ranges from 6,630 to $10,390 \mathrm{cal}$. yr BP, whereas the oldest gyttja covering the event layers is 6,600 cal. yr BP old. This means that the tsunami occurred between 6,600 and 6,630 cal. yr BP. Various causes of the tsunami event are considered, including the impact of meteorites within the coastal plain and the littoral zone of the southern Baltic Sea.
\end{abstract}

Key words: Baltic Sea, onshore tsunami deposits, age of tsunami, Holocene coastal changes, meteorite impact.

\section{INTRODUCTION}

In the last 30 years, there has been increasing interest in the causes, consequences and frequency of tsunami and palaeotsunami events (Bourgeois, 2009; Goff et al., 2014). Research has intensified as the result of the two megatsunamis that occurred in Thailand in 2004 and in Japan in 2011. However, it remains difficult to recognize tsunami events in the fossil record because their distinctive features, which include both sedimentological and geomorphologic imprints, are poorly known (Scheffers and Kelletat, 2003). To develop a catalogue of such features, increased field investigation of sediments deposited by modern tsunamis as well as those that took place in historical times are needed (Dawson, 1994; Dawson and Shi, 2000; Gelfenbaum and Jaffe, 2003; Scheffers and Kelletat, 2003; Dawson et al., 2004; Dawson and Stewart, 2007; Dominey-Howes, 2007; Kortegas and Dawson, 2007; Jaffe and Gelfenbaum, 2007; Morton et al., 2007; Choowong et al., 2008; Bour-

* Corresponding author, e-mail: rotnicki@amu.edu.pl

Received: April 13, 2016; accepted: April 24, 2016; first published online: May 13, 2016 geois, 2009; Goff et al., 2010; Engel and Brückner, 2011; Peterson and Cruikshank, 2011). The results will help to 1) detect palaeotsunami deposits in places where the probability of occurrence is low and their identification is often incidental and 2) verify knowledge of the frequency and locations at which tsunamis can occur on a global scale because events classified as tsunamis constitute and remain a fraction of a percent of the events responsible for coastal formation in the historical record (Scheffers and Kelletat, 2003). Geological study of tsunamis is a new field of research in part because palaeotsunamis can be increasingly identified in the geological records that are hidden beneath younger sediments and by subsequent relief topography (Dominey-Howes, 2002; Scheffers and Kelletat, 2003; Dominey-Howes et al., 2006).

The Baltic coast has suffered from frequent tsunamis in the past. The deglaciation of the last ice sheet caused a strong isostatic uplift of Scandinavia when the last glaciation gave way to the Holocene, a transition accompanied by numerous earthquakes that often had magnitudes greater than 8.5 on the Richter scale (Mörner, 1996, 1999, 2003, 2004, 2005, 2008a, b, 2011). Of the seismic events recorded since the beginning of Holocene, as many as 59 occurred below sea level and caused tsunamis. Their geologic record has been documented in 17 places along the Swedish coastline (Mörner, 1996, 1999, 2003, 2005, 2008a, b, 2011; Mörner and Dawson, 2011). The uplift 
rate of Scandinavia and the seismic activity of the area decreased throughout the Holocene, but has not reached zero until now (Kijko et al., 1993). Megatsunamis detected on the coast of Sweden and dated to the beginning of the Holocene (Mörner, 1996, 1999, 2003, 2005, 2008a, b) probably reached the southern coast of the Baltic Sea, which at that time was situated several tens of kilometres north of the present-day coastline, and the sea level was $45-50 \mathrm{~m}$ lower than it is today (Uścinowicz, 2003, 2006). The geological traces of these events are now either at the bottom of the southern part of the Baltic Sea at a depth of several metres or have been destroyed by the Holocene marine transgression, which reached the present coastal zone 7,500-8,000 cal. yr BP (Uścinowicz, 2003, 2006; Rotnicki, 2009). These data defined the lower age limit of the period during which a tsunami might have occurred on the present southern coast of the Baltic Sea.

No tsunami deposits have been recorded along the southern coast of the Baltic Sea for a long time, although in ancient chronicles there are some accounts describing extremely strong storm surges or potential tsunamis that occurred in historical times on the western coast of Poland. Recently, two continuous sandy layers containing brackish diatoms were found in a peat bog located $1.4 \mathrm{~km}$ from the coastline; they probably constitute a geological record of these events (Szczuciński, 2008; Piotrowski et al., 2013). AMS ${ }^{14} \mathrm{C}$ dating showed that these layers may have been deposited during extreme marine events that occurred in 1497 and 1757 and are recorded at different coastal sites (Piotrowski et al., 2013). If these were tsunamis, their origin is unknown. Although an earthquake of ca. 4.8 magnitude occurred in southern Sweden in 1497 (Kijko et al., 1993), there is no evidence these events were linked.

During research on changes in Baltic Sea level during the Holocene, the first succession of prehistoric deposits that exhibits the characteristics of tsunami deposits was discovered in the Gardno-Łeba Coastal Plain (along the middle coast of Poland; Rotnicki et al., 2008, 2009b). Drilling was used to determine the distribution of this succession and showed that it fills a bipartite hemispherical hollow. From 2010 to 2014, a complementary field survey was performed to obtain better data on the characteristics of the deposits.

The purpose of the paper is to present the results of this research and in particular to:

- describe the texture and structure of the tsunami deposits discovered,

- determine their distribution within a geological framework,

- estimate their age,

- discuss a hypothesis that explains the causes of this tsunami event,

- indicate the scale on which the coast was moulded by the tsunami.

\section{PALAEOGEOGRAPHIC AND GEOMORPHIC BACKGROUND OF THE SITE}

The Gardno- Łeba Coastal Plain is the largest lowland on the central part of the Polish coastline, which is a well-developed barrier-lagoon coast. The lowland is separated from the Pleistocene plateau by an erosional escarpment with a height of $20-60 \mathrm{~m}$ to the south and by a lobe-like thrust end moraine from the Gardno Phase (17,500-18,000 cal. yr BP), which marks the youngest ice advance in the area to the south-west (Fig. 1; Rotnicki and Borówka, 1995). The line denoting the maximum extent of the Holocene transgression of the south Baltic Sea was reached twice in the area (at 8,200-9,000 and 6,300-7,000 cal. yr BP; Rotnicki, 2009) and intersects the present-day Baltic coastline $4 \mathrm{~km}$ east of the mouth of the Łupawa River in the village of Rowy (Figs. 1 and 2). This line divides the Gardno-Łeba Coastal Plain into two parts. The western part, which is located inside the lobe of the thrust end moraine, has features of a postglacial landscape, which include the presence of ground moraines, kames and large ice tongue depressions. As the glacier retreated during the Gardno Phase, this depression was occupied by an ice-dammed lake. Its deposits glaciolacustrine clays over ten metres thick - are overlain by glaciofluvial sand and gravel. From the end of the last glaciation

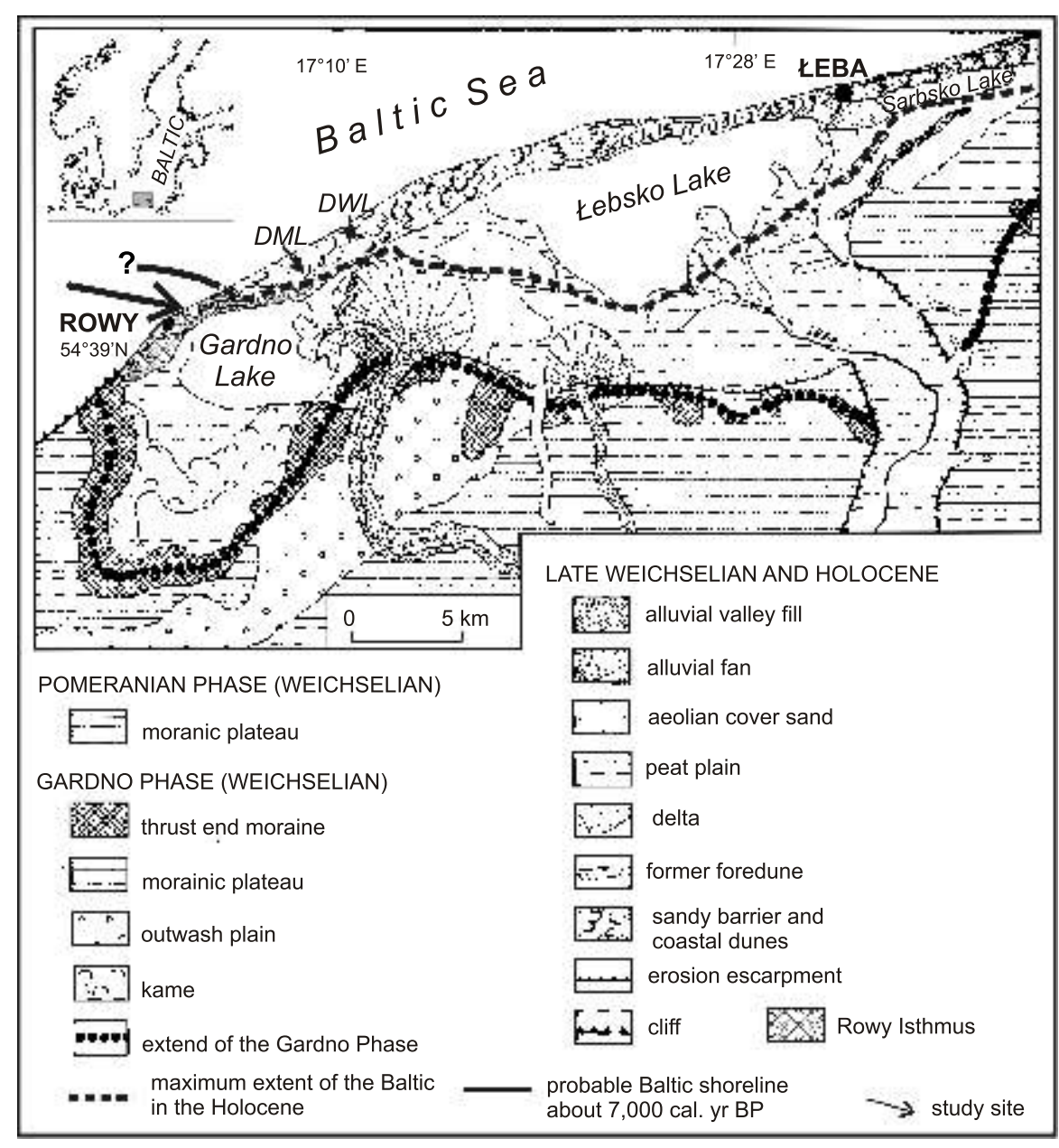

Fig. 1. The location of the study site and the main geomorphic features of the Gardno-Łeba Coastal Plain 


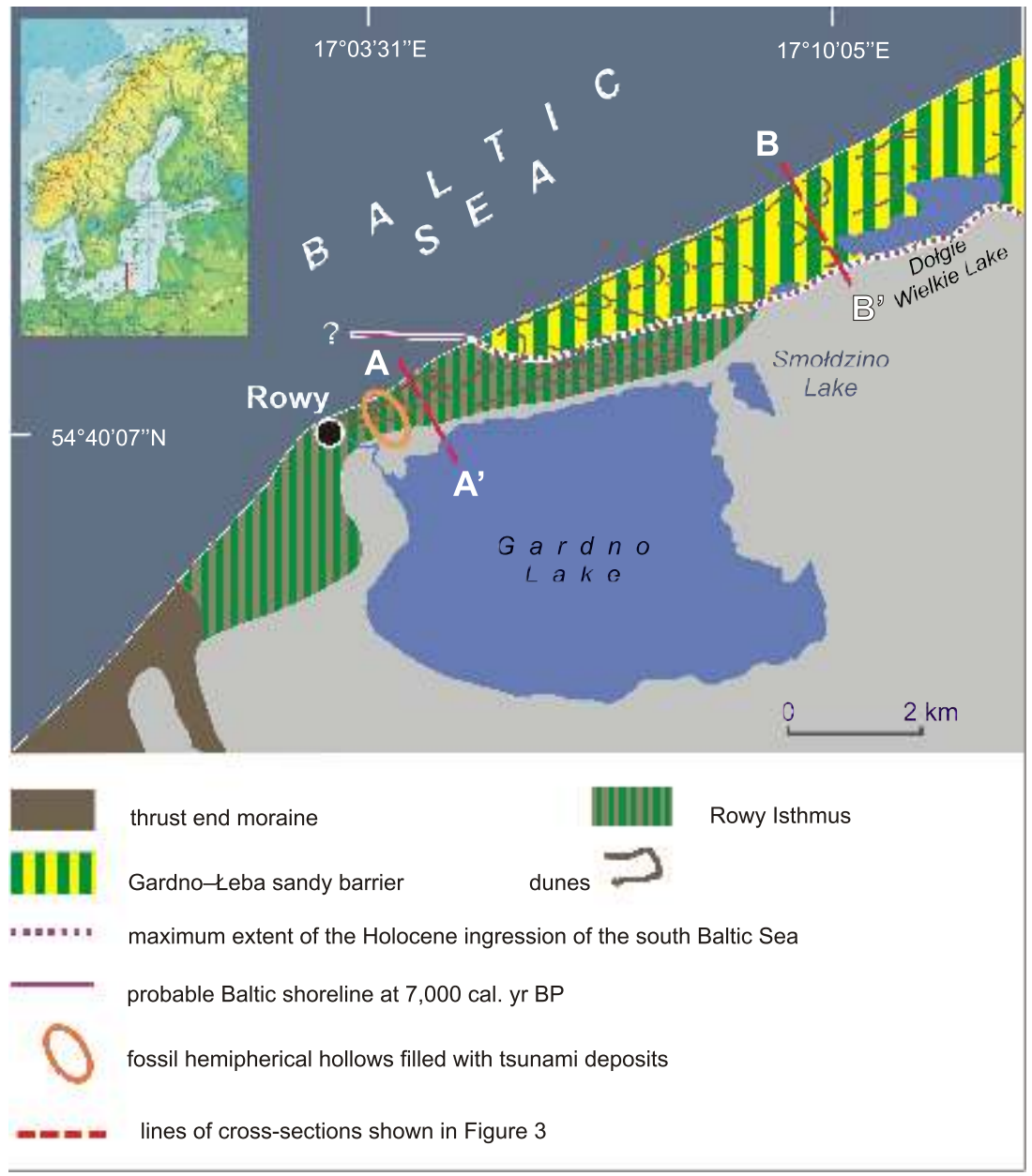

Fig. 2. The sites of fossil tsunami deposits in the Rowy Isthmus maximum range of the Middle Holocene transgressions is the youngest. It formed during the last few centuries, and its geological structure differs from that of the eastern part of the barrier. It is a single-phase barrier built of overwash sand deposited on the remnants of a Pleistocene plateau built from till overlain by a thick succession of dammed silt and clay as well as glaciofluvial sand and gravel from the post-Gardno Phase (Rotnicki, 2009b; Fig. 3B). This part of the barrier is called the "Rowy Isthmus" (Rotnicki et al., 2008, 2009b), and the tsunami deposits were found exactly there.

The entire Gardno-Łeba Barrier is covered with sand dunes. On the eastern part of the barrier, there is a field of active barchan-like dunes that reach heights of $40 \mathrm{~m}$ a.s.l., and the remaining part of the barrier is dominated by forested linear and arc dunes and a few barchan dunes (the height of the highest Czołpino dune is $56 \mathrm{~m}$ a.s.l.). The oldest dunes on the eastern part of the barrier are 3,000 yr old, and the parabolic dunes (which are up to $10 \mathrm{~m}$ high) in the Rowy Isthmus are 200-300 years old. The surface of the isthmus lies 2-3 $\mathrm{m}$ a.s.l., and the isthmus is ca. $1 \mathrm{~km}$ wide. The isthmus is separated from the beach by one or two foredune ridges.

\section{METHODS}

\section{GEOPHYSICAL METHODS}

The main purposes of the geophysical to the Atlantic Period, the area was an extensive peat bog (Rotnicki and Borówka, 1995), which, during the Littorina transgression of the Baltic Sea, evolved into Gardno Lake (Wojciechowski, 1990). However, according to Bogaczewicz-Adamczak et al. (1982), who performed a palynological and diatom analysis, the lake formed only in the sub-Atlantic Period.

The eastern part of the Gardno-Łeba lowland showed a completely different mode of sedimentation during the Late Glacial Period and the Holocene. During deglaciation, meltwaters formed in the northern part of the lowland two terraces, which subsequently became covered with overburden. The younger one is buried beneath the floors of Łebsko Lake and Dołgie Lake (Rotnicki, 2009). Rivers running from the Pleistocene plateau formed large alluvial fans in the southern part of the coastal plain between which peat bog plains existed. Two Holocene marine transgressions covered a large part of the coastal plain (Rotnicki, 2009). During the second ingression and the subsequent long-term stabilization of sea level at an elevation of approximately $-2 \mathrm{~m}$, the barrier-lagoon depositional system developed. It is estimated that this occurred at approximately 6,000 cal. yr BP. In the period between 4,100 and 4,800 cal. yr BP, the lagoons transformed into freshwater lakes (Łebsko and Sarbsko) that were separated from the sea by the Gardno-Łeba Barrier (Rotnicki et al., 1999b, 2009a; Rotnicki, 2010). The eastern part of the barrier formed during several phases of sea level fluctuation that caused the marine environment to shift to a lake via a lagoon (Fig. 3A). The section of the Gardno-Łeba Barrier located west of the line that denotes the survey (Fig. 4) were to determine the size of the bipartite fossil hemispherical hollows cut in the glaciolacustrine clays and to reconstruct the depositional architecture of the deposits that fill these hollows. The results of the geophysical research helped with planning of the number and sites of boreholes. The following investigations were conducted:

1. Vertical inductive sounding using an EM34-3 with three inter-coil spacings (10, 20 and $40 \mathrm{~m}$ ) and two dipole modes (horizontal - HD) and vertical - VD). Soundings were performed at 25 sites. The resulting maps of the apparent resistivity and conductivity showed two areas of anomalies with low resistivity. The anomalies are best identified on maps based on the results of a survey conducted with spacings of $H D=10 \mathrm{~m}$ and $\mathrm{HD}=20 \mathrm{~m}$ (Fig. 5). The white line in Figure 5 marks the extent of the fossil hollows that were later interpreted using the boreholes.

2. Direct-push electrical resistivity logging was performed using a sensor attached to the end of a steel pipe that was driven into the subsurface using a percussion hammer (Geoprobe Systems). Measurements were made at 30 sites located along meridional $\left(A-A^{\prime}\right)$ and latitudinal $\left(B-B^{\prime}\right)$ transects. The sensor was pushed until the glaciolacustrine clays of the post-Gardno Phase were reached, i.e., to a depth of 12.0-18.5 m b.g.s. (Fig. 6). The comparisons of the resistivity logs with the stratigraphic logs from the boreholes made in the preliminary survey showed that this geophysical method is useful for identifying particular types of deposit found in the substrate and within fossil hollows (Fig. 6). Resistivity cross-sections made 
A

N S

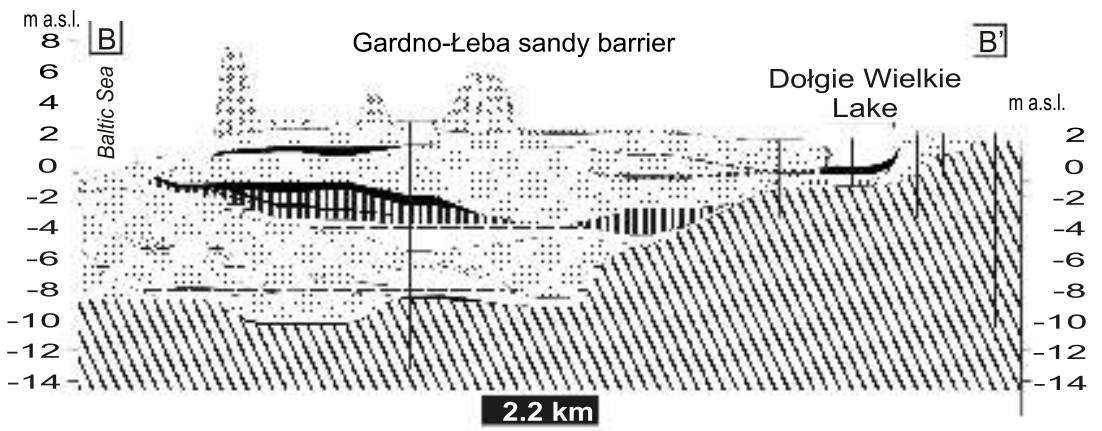

$\mathrm{N}$

$\mathrm{S}$

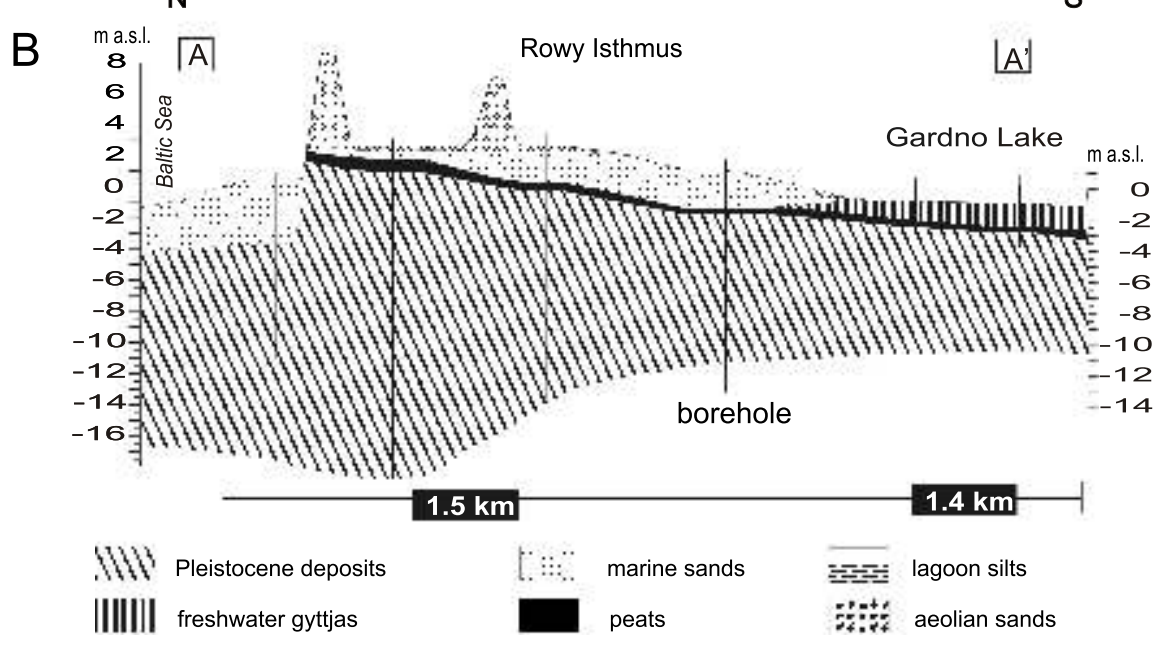

Fig. 3. Cross-sections of the Gardno-teba sandy barrier (A) and the Rowy Isthmus (B)

The location of cross-sections are marked in Figure 2

along both transects clearly showed the locus of the fossil hollows and the spatial differentiation of the lithology within the Rowy Isthmus (Fig. 7).

3. GPR profiling was performed along the main A-A' transect in the Rowy Isthmus (Fig. 4). The best results were obtained at a frequency of $50 \mathrm{MHz}$, at which the penetration depth reached $18 \mathrm{~m}$.

\section{GEOLOGICAL METHODS}

In the area of the fossil hollows, 33 boreholes were drilled. To analyse the palaeomorphology and depositional architecture of the sediments filling and surrounding these hollows, data from 32 drillings made in 2003-2008 as part of a previous project (Rotnicki, 2009) were used as supplements.

Drilling to a depth of 10-20 m b.g.s. was performed using a mechanical-hydraulic drilling machine called "Meres" (Rotnicki et al., 1999a). The spiral probe used for drilling was $1 \mathrm{~m}$ long and $0.08 \mathrm{~m}$ in diameter; the spiral pitch was $0.05 \mathrm{~m}$. The deposit cores were cleaned, and $0.05 \mathrm{~m}$ thick samples were collected.

For the sedimentary logs, sieve particle size analysis (PSA) was performed. A total of 228 sand samples from three logs (L424, L501 and L507) located in a geological cross-section along the A-A' transect (Fig. 8) were collected. All the samples were dried at $105^{\circ} \mathrm{C}$ for $48 \mathrm{~h}$, treated with $\mathrm{H}_{2} \mathrm{O}_{2}$ to remove organic matter, dried again and sieved at 3 phi intervals (from -2 to 4 phi). The grain-size statistics were calculated using the method of moments (logarithmic $\Phi$ ) in Gradistat (Blott and Pye, 2001).

The Kolmogorov-Smirnov test statistic was employed to provide a measure of the similarity of the grain-size distributions of the tsunami deposits (TD) and the marine overwash sand (MOS) overlying the TD. Similarity matrices were generated for the succession of deposits found in logs L424, L501, and L507. The analysis aimed to compare the hydrodynamic conditions of deposition of these two types of sediment.

The malacological analysis and analysis of the plant macrofossils found in the tsunami deposits encompassed 57 samples collected from four sediment logs: L500, L501, L504, and L505. The organic matter was removed using perhydrol. To collect the shell debris, samples were washed through a 1 phi sieve. Shells fragments were identified and counted using a Nikon AZ 100 stereoscopic microscope. The taxonomic classification was based on studies by Jagnow and Gosselck (1987), Skompski (1991) and Piechocki and Dyduch-Falinowska (1993). To determine the number of molluscs from the number and size of fragments, Ložek's (1964) procedure was applied. 


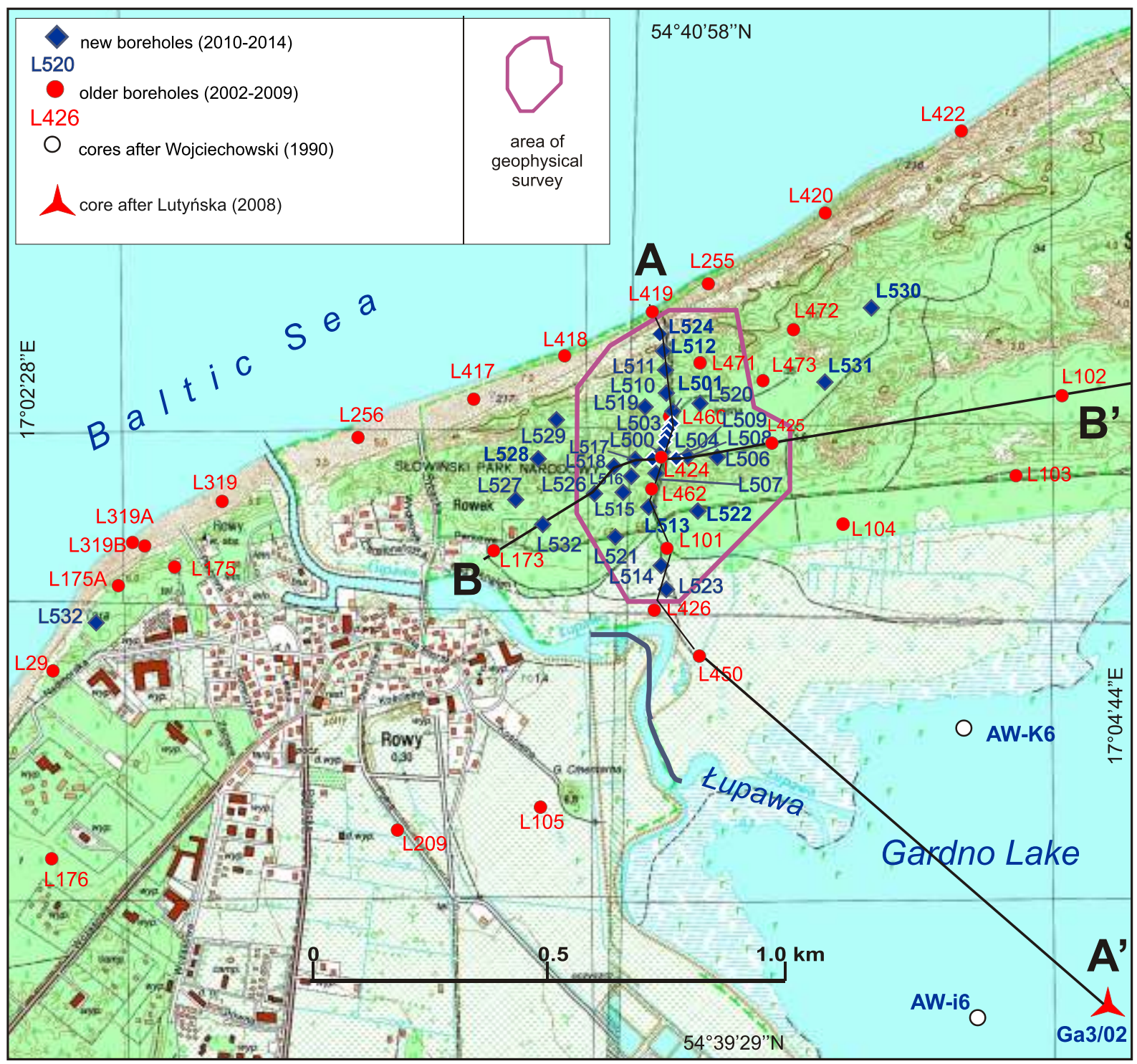

Fig. 4. The location of the geophysical survey, boreholes and core soundings
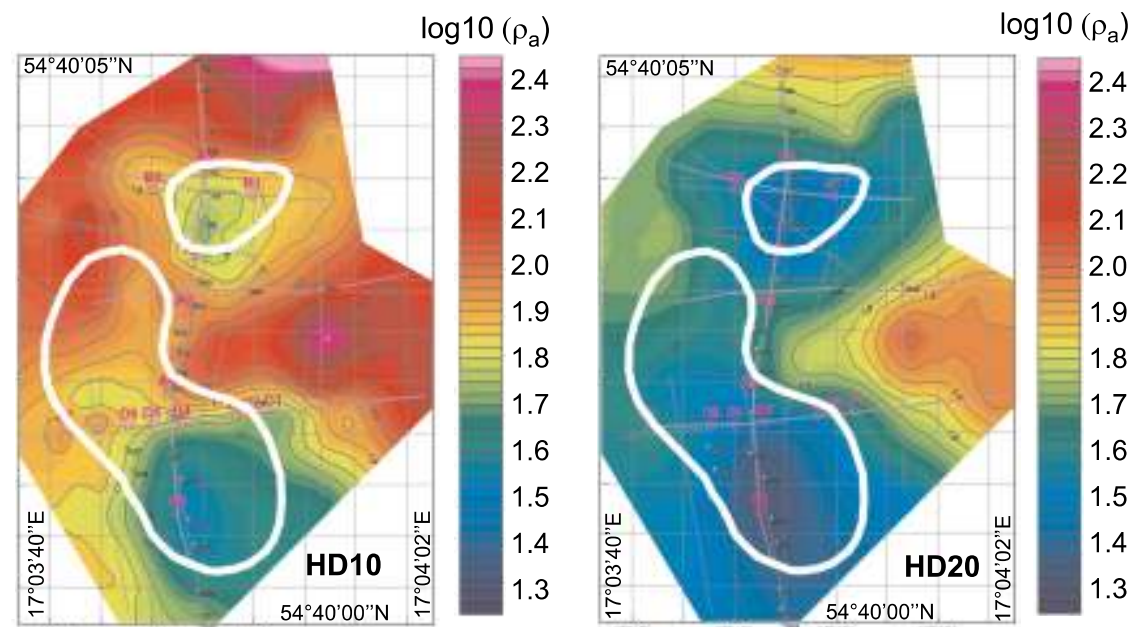

Fig. 5. Apparent resistivity and conductivity charts obtained by means of vertical inductive sounding with dipole spacing $\mathrm{HD}$ $=10 \mathrm{~m}$ and $\mathrm{HD}=20 \mathrm{~m}$

The white line marks the extension of the fossil hollows, which were interpreted later using data from boreholes 
N

\section{$S$}

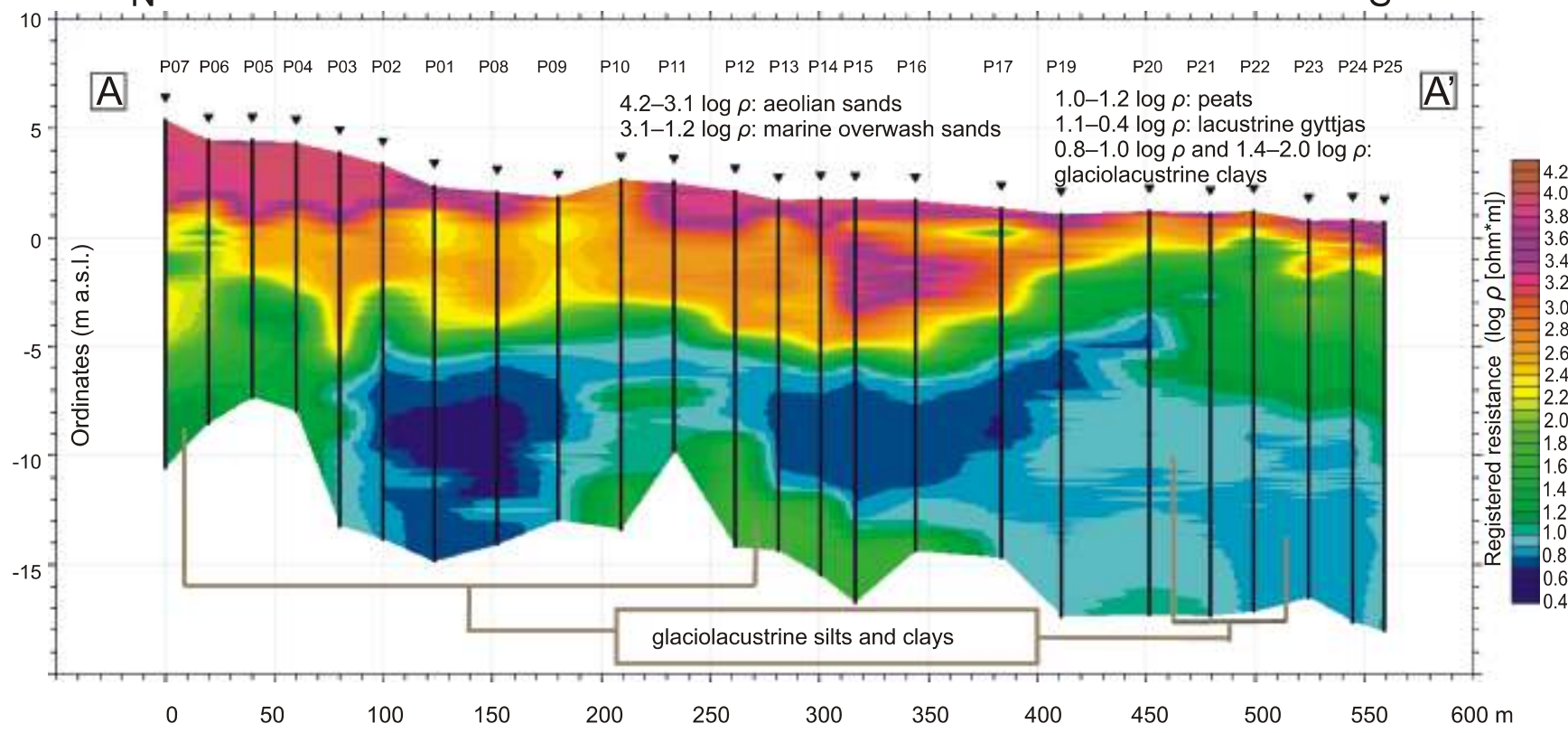

Fig. 6. The apparent resistivity $\left(\log \rho\left[0 \mathrm{hm}^{*} \mathrm{~m}\right]\right)$ interpolated along the meridional cross-section $\left(\mathrm{A}-\mathrm{A}^{\prime}\right)$ of the Rowy Isthmus

Dark blue marks the fossil hemispherical hollows

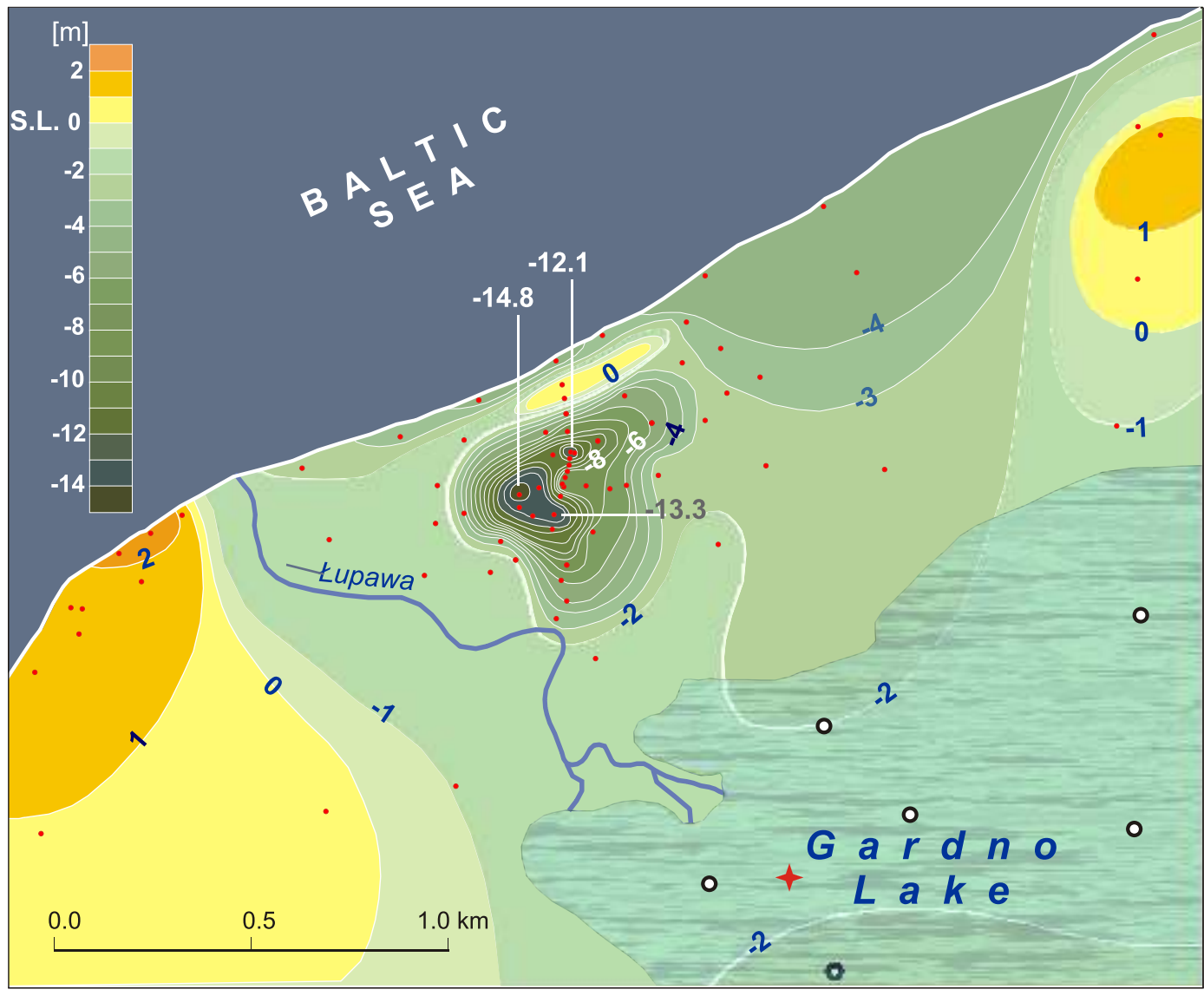

- borehole O sediment core after Wojciechowski (1990) † sediment core after Lutyńska (2008)

Fig. 7. The Rowy Isthmus and the elevations of the bottoms of the hemispherical hollows 


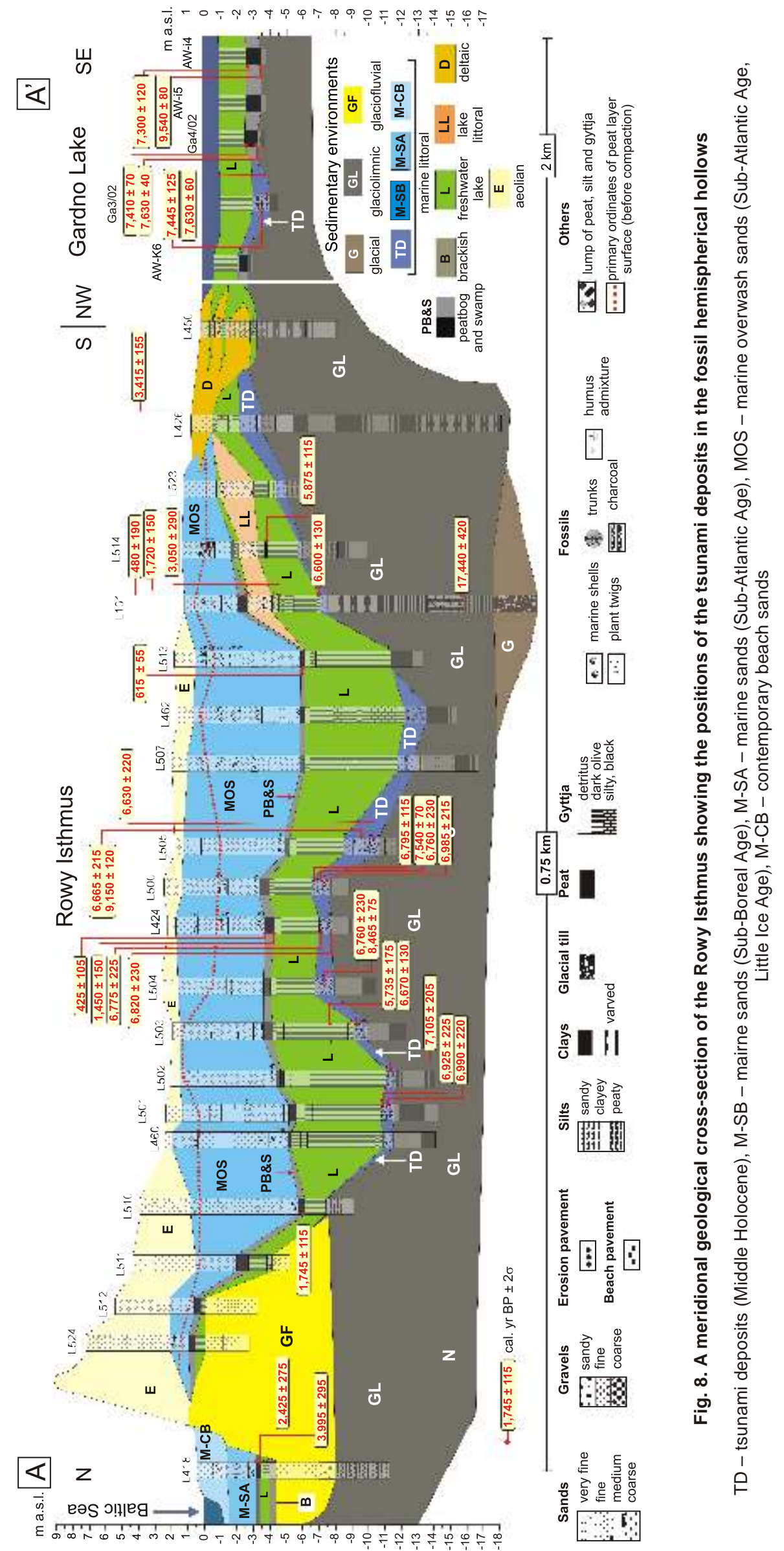


Additionally, a taxonomic analysis of the seeds found in the sand samples was performed. All these data were supplemented by a diatom analysis performed as part of a previous project (Rotnicki et al., 2009b).

The age of the organic matter collected from the sand samples was determined using the $\mathrm{AMS}{ }^{14} \mathrm{C}$ method (31 samples) at the Poznań Radiocarbon Laboratory and by the conventional method (18 samples) at the Gliwice Radiocarbon Laboratory. A total of 49 samples were used to estimate the age of the tsunami event; the types of material used in the dating were peat (20), shells of Cerastoderma sp. (13), calcareousless gyttja (6), wood (5), lumps of peat (3), lumps of silt (2), and charcoal (1) (see Table 1). OxCal v. 4.2.3 was used for calibration (Bronk Ramsey and Lee, 2013). For the Cerastoderma shells, the marine radiocarbon correction was made using the software's Marine 13 curve (Reimer et al., 2013). The means and intervals of the calendar ages are given, and the true ages of the samples provided have probabilities of ca. $95 \%$.

The preliminary hypothesis for the cause of the Rowy tsunami was a meteorite impact. It was based on the presence of one microspherule composed of pure iron within the tsunami layer (M. Michalik in Rotnicki et al., 2009b). Therefore, a study aimed to determine the content of the extraterrestrial matter. To do this, the following procedure was adopted. The volumetric magnetic susceptibility of the sediment samples from complete logs L500 and L501 (total 346 samples) and of 62 additional samples collected from the tsunami layer found in other logs was determined using a Bartington MS2B magnetometer with a low-frequency $(0.46 \mathrm{kHz})$ alternating magnetic field. To determine the cause of the positive excursion of the magnetic susceptibility, the heavy minerals were analysed. The heavy minerals were separated from the $10 \mathrm{~g}$ samples with grain sizes of 2-3 phi using a sodium polytungstate liquid with a density of
$2.84 \mathrm{~g} / \mathrm{cm}^{3}$. Because spherules of cosmic origin are highly magnetic, a neodymium magnet was used to separate the magnetic and non-magnetic fractions of the heavy mineral assemblage obtained. The magnetic fraction was later placed within a strong magnetic field produced by a permanent magnet. The magnet was placed over the sample - first at a distance of $\sim 10$ centimetres, then at several centimetres and eventually at $1 \mathrm{~cm}$. The magnet was separated from the samples by a sheet of paper. The grains collected were covered with graphite and analysed using a Hitachi $3700 \mathrm{~N}$ scanning electron microscope paired with a Noran SIX EDS, which allowed the chemical compositions of microareas to be determined.

\section{PALAEORELIEF AND LITHOLOGY OF THE TSUNAMI SUBSURFACE}

The tsunami deposits occur in a fossil hemispherical and bipartite hollow that is cut in deposits from the Gardno Phase, which is the youngest ice advance in the Polish lowlands (Rotnicki and Borówka, 1995). The succession starts with glacial till, which is overlain by ice-dammed glaciolacustrine clays, partly varved, and covered by glaciofluvial sand and gravel. The thickness of the ice-dammed deposits exceeds $15 \mathrm{~m}$. A thin layer of peaty silt within the blue-grey glaciolacustrine clay is $17,210-17,630$ cal. yr BP (Gd-4776) and slightly younger than the thrust end moraine of the Gardno Phase (Rotnicki and Borówka, 1995). The sole of the Holocene deposits in the western and eastern parts of the Rowy Isthmus lies at an ordinate of 1-3 $m$ a.s.l., whereas in the middle part of the isthmus it is lower at -1 to $-2 \mathrm{~m}$ b.s.l. (Figs. 7-9). South of the isthmus and currently in Gardno Lake, the sole of the Lower Holocene peat is

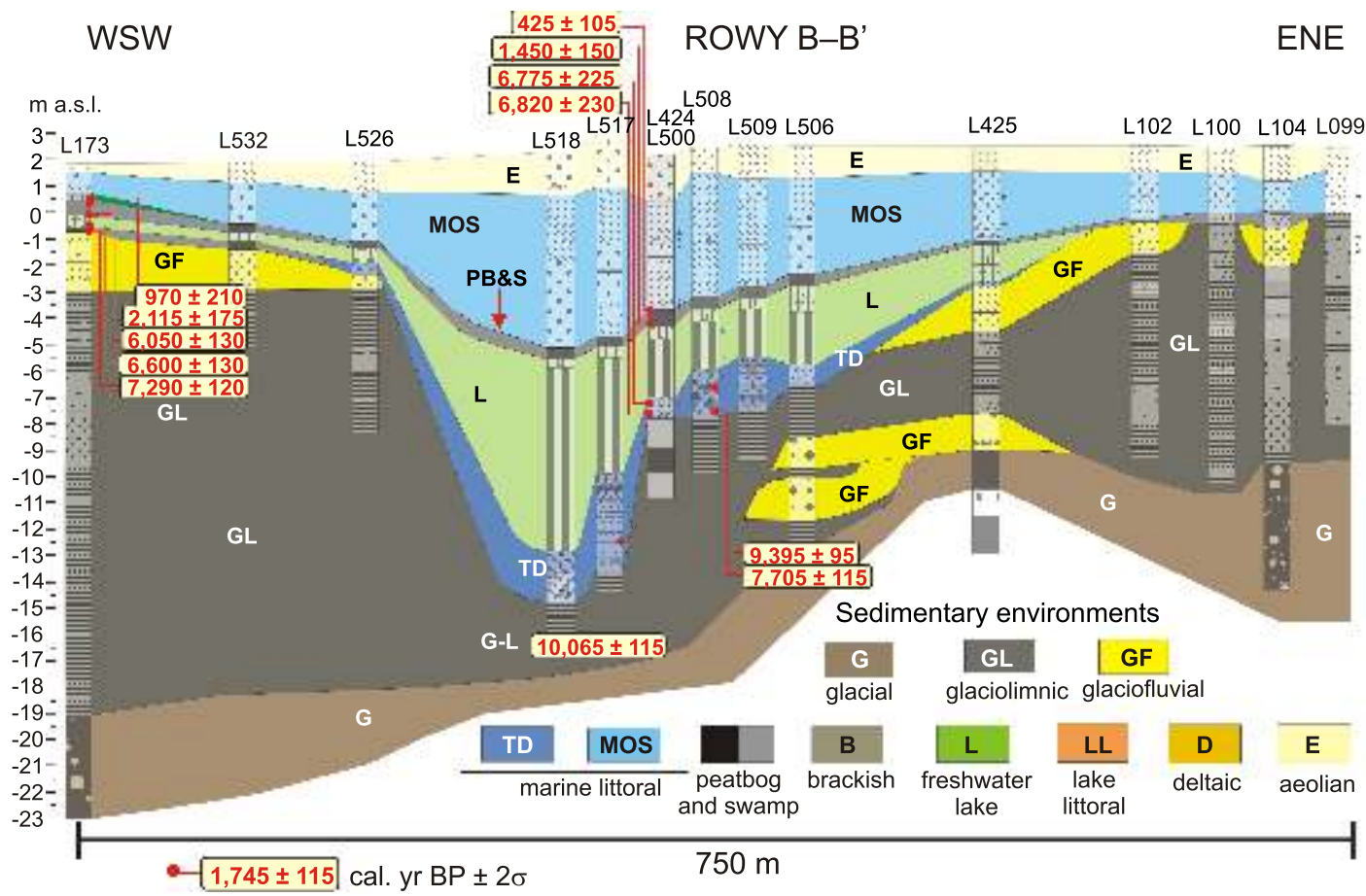

Fig. 9. A longitudinal geological cross-section of the Rowy Isthmus showing the positions of the tsunami deposits in the fossil hemispherical hollows 
Radiocarbon ages of different materials at the Rowy site

\begin{tabular}{|c|c|c|c|c|c|}
\hline & $\begin{array}{l}\text { Sample } \\
\text { number }\end{array}$ & $\begin{array}{l}\text { Material } \\
\text { dated }\end{array}$ & $\begin{array}{l}\text { Uncorrected } \\
{ }^{14} \mathrm{C} \text { ages } \\
\text { [years BP] }\end{array}$ & $\begin{array}{l}\text { Calibrated age interval } \\
( \pm 2 \sigma) \text { and mean BP } \\
\text { (max-mean-min) }\end{array}$ & $\begin{array}{l}\text { Laboratory } \\
\text { number }\end{array}$ \\
\hline \multicolumn{6}{|c|}{ deposits in situ covering the tsunami layer } \\
\hline 1. & L424/27 & peat & $420 \pm 45$ & $530-425-320$ & Gd-12680 \\
\hline 2. & L101/14 & peat & $470 \pm 120$ & $670-480-290$ & Gd-6570 \\
\hline 3. & L513/78 & peat & $645 \pm 25$ & $670-615-560$ & Poz-49608 \\
\hline 4. & $\mathrm{~L} 481 / 1$ & peat & $825 \pm 30$ & $790-740-690$ & Poz-49615 \\
\hline 5. & L173/7 & brown gyttja (-Ca) & $1,040 \pm 90$ & $1,180-970-760$ & Gd-11388 \\
\hline 6. & L424/31 & peat & $1,550 \pm 80$ & $1,600-1,450-1,300$ & Gd-15708 \\
\hline 7. & L101/18 & peat & $1,800 \pm 60$ & $1,870-1,720-1,570$ & Gd-7019 \\
\hline 8. & L510/0 & peat & $1,825 \pm 30$ & $1,860-1,745-1,570$ & Poz-49607 \\
\hline 9. & L173/8 & peat & $2,100 \pm 50$ & $2,300-2,115-1,940$ & Gd-12694 \\
\hline 10. & L418/4 & peat & $2,330 \pm 75$ & $2,700-2,425-2,150$ & Gd-15715 \\
\hline 11. & L525/1 & peat & $2,820 \pm 30$ & $3,010-2,930-2,850$ & Poz-49614 \\
\hline 12. & L101/30 & detritus gyttja (-Ca) & $2,870 \pm 120$ & $3,340-3,050-2,760$ & Gd-6580 \\
\hline 13. & L426/19 & detritus gyttja (-Ca) & $3,195 \pm 55$ & $3,570-3,415-3,260$ & Gd12695 \\
\hline 14. & L418/6 & peat & $3,650 \pm 100$ & $4,290-3,995-3,700$ & Gd-15699 \\
\hline 15. & L98/12 & black gyttja (-Ca) & $4,180 \pm 60$ & $4,850-4,690-4,530$ & Gd-7020 \\
\hline 16. & L503/7 & Cerastoderma sp. & $5,270 \pm 35$ & $5,910-5,735-5,560$ & Poz-49458 \\
\hline 17. & L514/47 & peat & $5,150 \pm 40$ & $5,990-5,875-5,760$ & Poz-49609 \\
\hline 18. & $\mathrm{~L} 173 / 10$ & peat & $5,275 \pm 50$ & $6,180-6,050-5,920$ & Gd-12659 \\
\hline 19. & $\mathrm{~L} 173 / 13$ & detritus gyttja (-Ca) & $5,790 \pm 120$ & $6,880-6,600-6,320$ & Gd-15703 \\
\hline 20. & L101/51 & detritus gyttja (-Ca) & $5,790 \pm 50$ & $6,730-6,600-6,470$ & Gd-7018 \\
\hline \multicolumn{6}{|c|}{ redeposited macrofossils in the tsunami layer } \\
\hline 21. & L505/45 & Cerastoderma sp. & $6,110 \pm 40$ & $6,850-6,630-6,410$ & Poz-49461 \\
\hline 22. & L505/37B & Cerastoderma sp. & $6,140 \pm 40$ & $6,880-6,665-6,450$ & Poz-49460 \\
\hline 23. & L503/12 & lump of peat & $5,870 \pm 35$ & $6,800-6,670-6,540$ & Poz-49600 \\
\hline 24. & L500/189A & Cerastoderma sp. & $6,220 \pm 40$ & $6,990-6,760-6,530$ & Poz-49452 \\
\hline 25. & L504/36A & Cerastoderma sp. & $6,220 \pm 40$ & $6,990-6,760-6,530$ & Poz-49459 \\
\hline 26. & L424/433/2 & Cerastoderma sp. & $6,230 \pm 40$ & $7,000-6,775-6,550$ & Poz-8261 \\
\hline 27. & Ga 3/02** & Cerastoderma sp. & $6,250 \pm 40$ & $6,900-6,790-6,680$ & Poz-9852 \\
\hline 28. & L500/183 & organic mud (lump) & $5,970 \pm 39$ & $6,910-6,795-6,680$ & Poz-49598 \\
\hline 29. & L43216/70 & Cerastoderma sp. & $6,260 \pm 40$ & $7,050-6,820-6,590$ & Poz-8262 \\
\hline 30. & L501/136 & Cerastoderma sp. & $6,350 \pm 40$ & $7,150-6,925-6,700$ & Poz-49455 \\
\hline 31. & L500/195 & Cerastoderma sp. & $6,405 \pm 35$ & $7,200-6,985-6,770$ & Poz-49454 \\
\hline 32. & L501/144 & Cerastoderma sp. & $6,410 \pm 40$ & $7,210-6,990-6,770$ & Poz-49456 \\
\hline 33. & L502/19 & Cerastoderma sp. & $6,520 \pm 40$ & $7,310-7,105-6,900$ & Poz-49457 \\
\hline 34. & L500/189B & wood & $6,670 \pm 40$ & $7,610-7,540-7,470$ & Poz-49599 \\
\hline 35. & L508/13 & lump of peat & $6,950 \pm 40$ & $7,920-7,805-7,690$ & Poz-49604 \\
\hline 36. & $\mathrm{Ga3} / 03^{* *}$ & peat & $7,060 \pm 40$ & $7,960-7,860-7,760$ & Poz-9851 \\
\hline 37. & L504/36B & wood & $7,650 \pm 40$ & $8,540-8,465-8,390$ & Poz-49601 \\
\hline 38. & L505/37A & wood & $8,190 \pm 40$ & $9,270-9,150-9,030$ & Poz-49603 \\
\hline 39. & L522/7 & charcoal & $8,200 \pm 40$ & $9,280-9,155-9,030$ & Poz-49612 \\
\hline 40. & L522/15 & plant macrofossils & $8,320 \pm 40$ & $9,470-9,310-9,150$ & Poz-49613 \\
\hline 41. & L508/24 & wood & $8,380 \pm 40$ & $9,490-9,395-9,300$ & Poz-49605 \\
\hline 42. & L517/26 & lump (shred) of peat & $8,940 \pm 50$ & $10,220-10,065-9,910$ & Poz-49610 \\
\hline 43. & L520/20 & wood & $9,220 \pm 50$ & $10,520-10,390-10,250$ & Poz-49611 \\
\hline \multicolumn{6}{|c|}{ deposits in situ older than the tsunami layer } \\
\hline 44. & $\mathrm{~L} 173 / 15$ & peat & $6,340 \pm 90$ & $7,410-7,290-7,170$ & Gd-12078 \\
\hline 45. & $A W-i 4 a^{*}$ & peat & $6,350 \pm 90$ & $7,420-7,300-7,180$ & Gd-1553 \\
\hline 46. & Ga4/02** & peat & $6,530 \pm 40$ & $7,480-7,410-7,340$ & Poz-9854 \\
\hline 47. & $\mathrm{Ga} 4 / 04^{* *}$ & peat & $6,790 \pm 40$ & $7,690-7,630-7,570$ & Poz-9853 \\
\hline 48. & $A W-i 4 b^{*}$ & peat & $8,550 \pm 90$ & $9,780-9,540-9,310$ & Gd-1554 \\
\hline 49. & L101/81 & peaty silt & $14,310 \pm 150$ & $17,860-17,440-17,020$ & Gd-4776 \\
\hline
\end{tabular}

Dating marked Poz and Gd were made by AMS ${ }^{14} \mathrm{C}$ method at the Poznań Radiocarbon Laboratory and by the conventional method at the Gliwice Radiocarbon Laboratory, respectively; ${ }^{*}$ - data after Wojciechowski (1990), ${ }^{* *}$ - data after Lutyńska (2008) 
found at -2 to -3.0 ) $m$ b.s.l. The peat is overlain by a layer of gyttja that is < 1 m thick (Wojciechowski, 1990; Lutyńska, 2008). The current depth of Gardno Lake averages $1.3 \mathrm{~m}$ (Wojciechowski, 1990).

The contour line at -2 to $-3 \mathrm{~m}$ b.s.I. marks the fossil bipartite hollow in the subsurface of the Holocene deposits (Fig. 7). At this depth, its diameter is ca. $625 \mathrm{~m}$, but at the ordinate of $-8 \mathrm{~m}$ b.s.l., it is divided into two smaller hollows: a southwestern hollow with a diameter of ca. $250 \mathrm{~m}$ and a northeastern hollow with a diameter of $130 \mathrm{~m}$. The bottoms of the hollows are -13.3 to -14.8) $\mathrm{m}$ b.s.l. and $-12.1 \mathrm{~m}$ b.s.l. deep, respectively, i.e., 10-12 m beneath the sole of the Holocene lacustrine gyttja deposited in Gardno Lake (Fig. 8).

\section{CHARACTERISTICS OF THE TSUNAMI LAYER}

Tsunami deposits (TD) cover the bottom and slopes of the fossil hollows and the saddle separating two subhollows (Figs. 8 and 9). The Rowy Isthmus is 500-600 m wide along meridional cross-section A-A'; it begins in the north, $180 \mathrm{~m}$ south of the present coastline (log L510) and ends in the backward delta of the Łupawa River (log L426; Fig. 8). The TD are also traced beneath the lacustrine gyttja accumulated on the floor of Gardno Lake, which is $1800 \mathrm{~m}$ south of the present coast of the Baltic Sea (Fig. 8). Along latitudinal cross-section B-B', the hollow extends for $400 \mathrm{~m}$ between logs L173 and L425 (Fig. 9). The sole of the TD lies between $-14.8 \mathrm{~m}$ b.s.I. (L518) and $-3.5 \mathrm{~m}$ b.s.I. (L426). The thickness of the TD varies from $0.23 \mathrm{~m}$ to $3.05 \mathrm{~m}$ and averages $1.09 \mathrm{~m}$, which is significantly greater than the thicknesses of tsunami layers reported from along low-energy coasts around the world. Data from such coasts show that tsunami layers are usually $1-50 \mathrm{~cm}$ thick and are often $<5 \mathrm{~cm}$ thick (Hindson et al., 1996; Benson et al., 1997; Clague et al., 2000; Dawson and Shi, 2000; Goff et al., 2000; Smoot et al., 2000; Bryant and Nott, 2001; Scheffers and Kelletat, 2003; Jaffe and Gelfenbaum, 2007; Morton et al., 2007; Abrantes et al., 2008; Choowong et al., 2008; Peterson et al., 2008; Fujino et al., 2008; Goff et al., 2010; Peterson and Cruikshank, 2011; Peterson et al., 2013). The relatively large thickness of the TD at Rowy is probably caused by the subsurface palaeorelief. Thicker (up to $2 \mathrm{~m}$ ) tsunami deposits have been reported only in areas of terrain lowering such as lagoons and lakes and in front of different obstructions (Clague et al., 1994a, b; Dawson, 1994; Peters et al., 2001; Smith et al., 2007; Vött et al., 2009; Goff et al., 2010).

The thickest TD at Rowy were found on the bottom and on the northern slope of the SW hollow (Fig. 8). Due to the subsurface relief, the transport capacity of the tsunami waves probably decreased here, causing the rapid deposition of the thick layer. The TD lie on the ice-dammed lake deposits that were cut by erosion (Fig. 10). Erosional contact with subsurface deposits is one of diagnostic features of tsunamis (Dawson, 1994; Clague et al., 2000; Fujiwara et al., 2000; Goff et al., 2000; Peters et al., 2001; Dominey-Howes et al., 2006; Dawson and Steward, 2007; Dominey-Howes, 2007; Morton et al., 2007; Peters et al., 2007; Mamo et al., 2009; Engel and Brückner, 2011).

The tsunami deposits at Rowy are characterized by chaotic arrangements of mineral grains and allochthonous organodetrital material, including marine shells and their detritus, lumps and rip-up clasts of peat, organic silt and glaciolacustrine clays (Figs. 11 and 12). By volume, this allochthonous material prevails over the mineral material in some parts of the sedimentary logs. The TD also contain numerous lumps of charcoal that are up to $10-15 \mathrm{~cm}$ across (Fig. 13) and a significant accumulation of densely packed pieces of wood, branches, and tree trunks (Pinus sp.; Fig. 13). Most of the deposits recorded in the sedimentary logs are massive and contain no internal lamination. The chaotic deposition of the TD is reflected in the age of the shells and wood: very often, older macrofossils occur above younger ones (Figs. 8, 9, and 11). All these features are diagnostic of tsunami deposits (Dawson, 1994; Clague et al., 2000; Bryant and Nott, 2001; Bondevik et al., 2005; Jaffe and Gelfenbaum, 2007; Dawson and Stewart, 2007; Morton et al., 2007; Peters et al., 2007; Smith et al., 2007; Choowong et al., 2008; Mamo et al., 2009; Engel and Brückner, 2011) and testify to the rapid deposition of sand settling out from the tsunami's waves.

The chaotic arrangement of components of different origin observed in most parts of the boreholes shows that the deposit has the features a dumped deposit (Bryant and Nott, 2001; Dominey-Howes, 2007; Peters et al., 2007). However, some trends in the composition and distribution of the TD are observed. First, the composition of the tsunami layer changes spatially - the content of shells and their debris decreases towards the south, whereas the amount of wood (branches, trunks and charcoal) increases. Because sand mixed with biogenic detritus was transported by waves from the north, this spatial differentiation of the TD' composition seems understandable. The loss in wave energy that resulted from friction on the sea-floor and a
L503

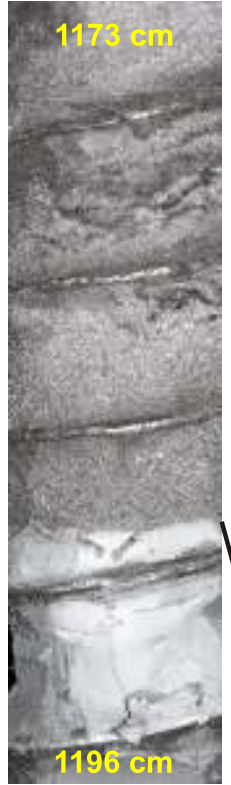

L505

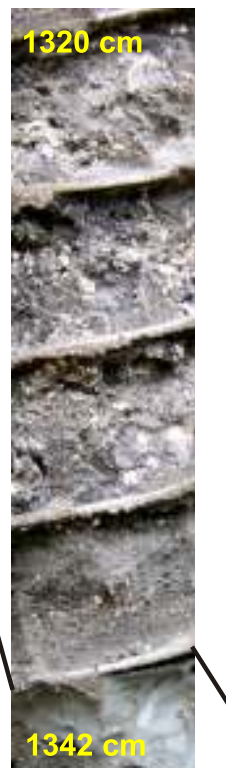

L508

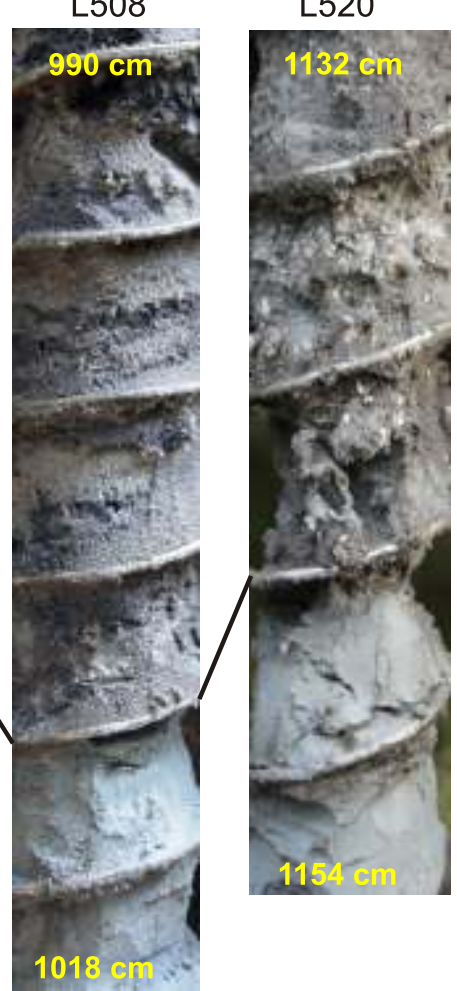

Fig. 10. The lower part of the tsunami layer, which exhibits an erosive contact with the underlying blue-grey glaciolacustrine clay

The tsunami deposits consist of marine sand mixed with shells and their debris (L505 and L520); they also contain strips of plant macrofossils and charcoal lumps (L508); the yellow numbers denote the depth below the ground surface 


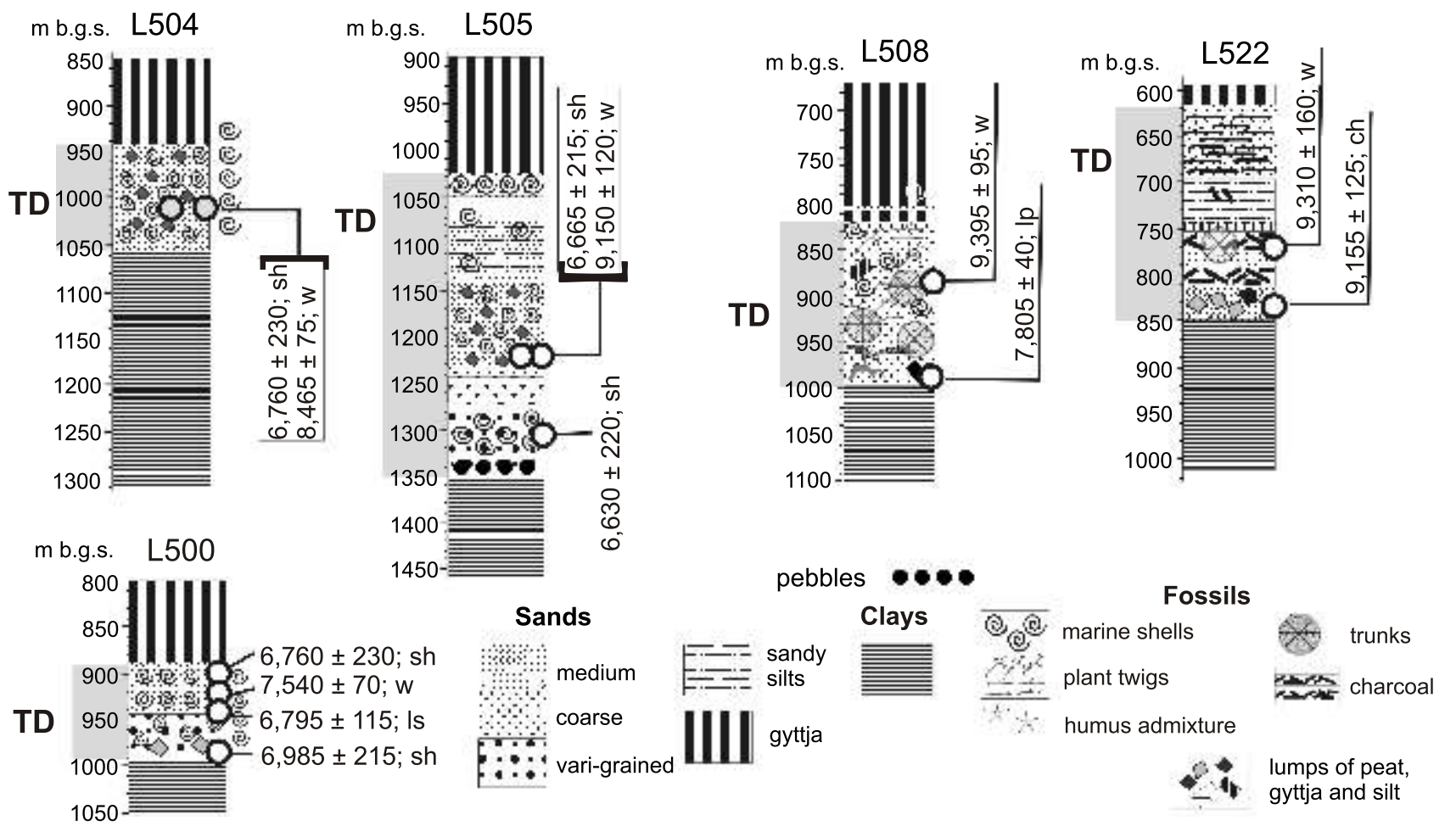

Fig. 11. Selected successions of deposits containing tsunami sand, silty sand and sand and gravel with pebbles

The tsunami deposits are rich in marine shells and their debris, lumps of peat, silt and clay, plant twigs and branches, and trunks of pine (Pinus sp.); allochthonous material of different ages occurs in the same layer (L504, L505), and in some places a "stratigraphic inversion" of bioclasts occurs (L500, L505, L508 and L522); sh - shell, w - wood, ch - charcoal, Is - lump of silt, Ip - lump of peat, TD - tsunami deposit; $6,795 \pm 115$ in cal. yr BP

L500

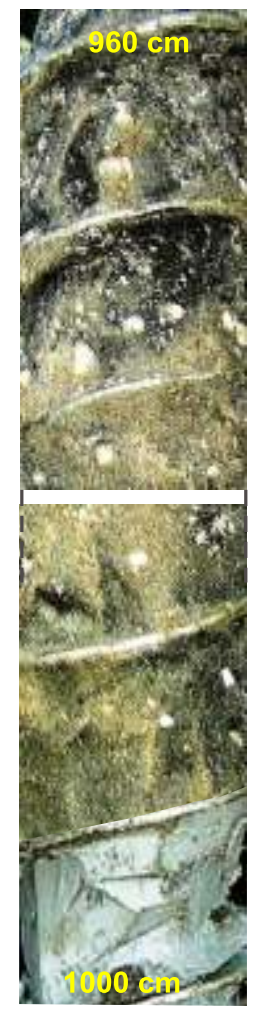

L502

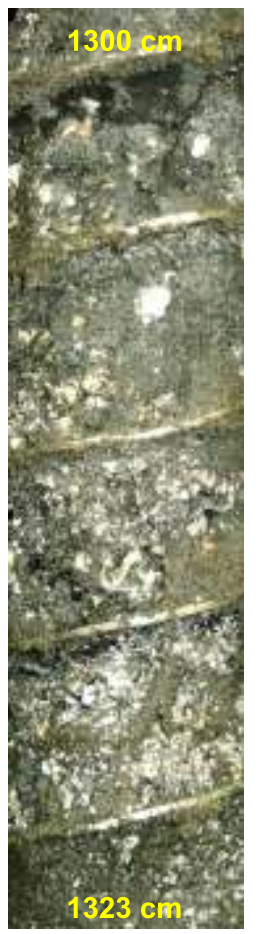

L517

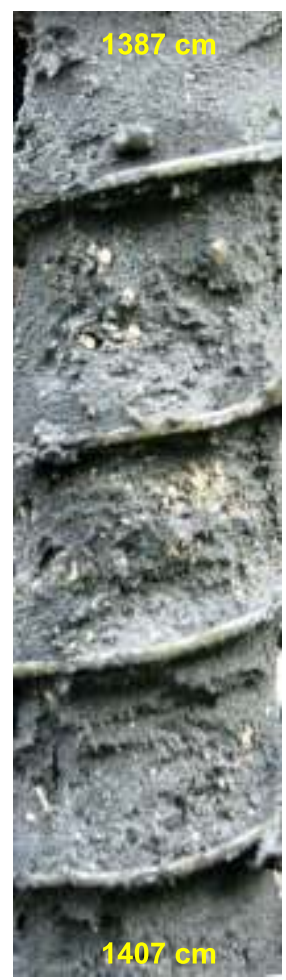

L520

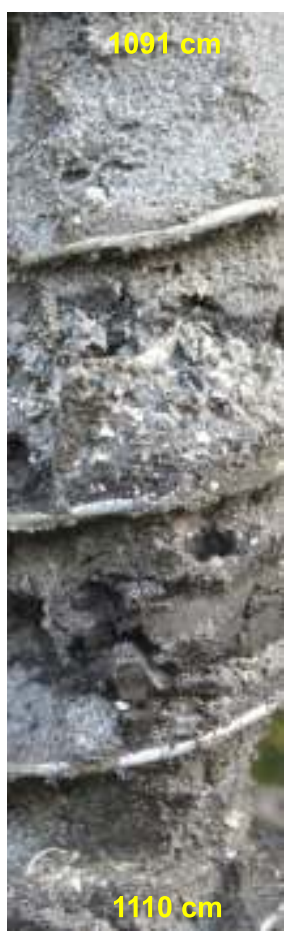

L520

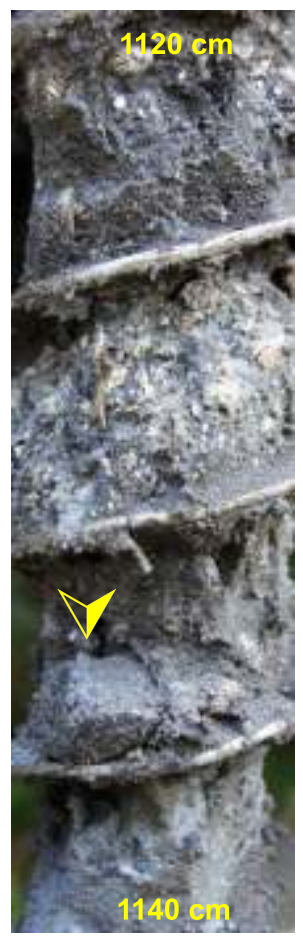

Fig. 12. The tsunami deposits at Rowy

These are characterized by an abundance of marine shells and their debris (selected cores), large lumps of organic silt (L520) and individual pebbles that occur mainly at the bottom of the tsunami layer (L520: yellow arrow); the yellow numbers denote the depth below the ground surface 
A

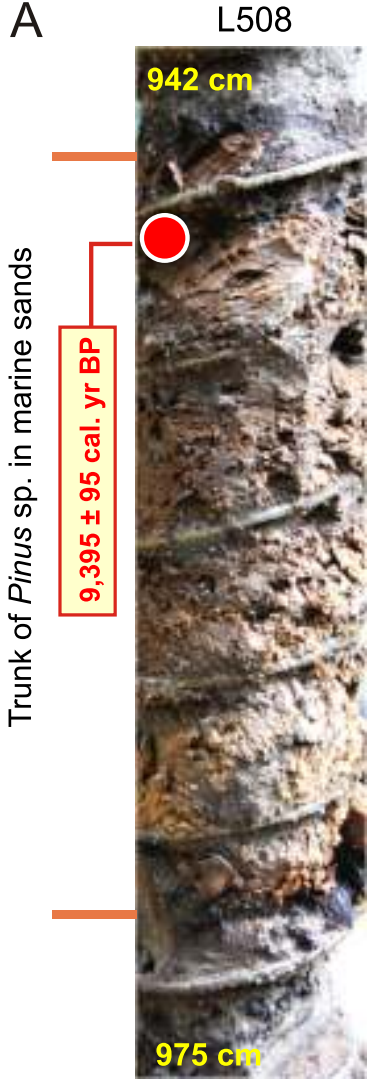

L509

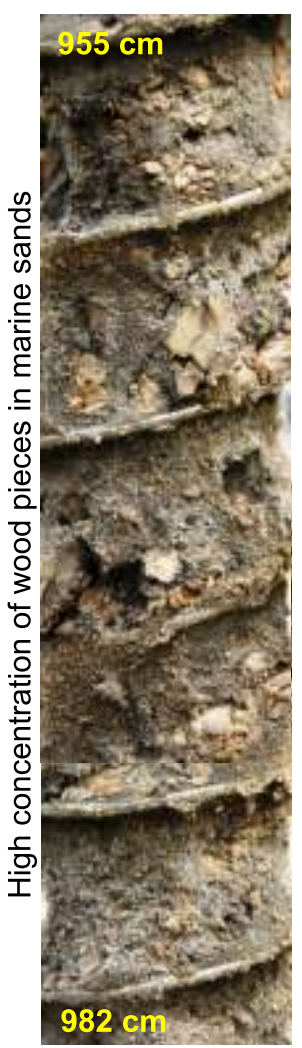

B

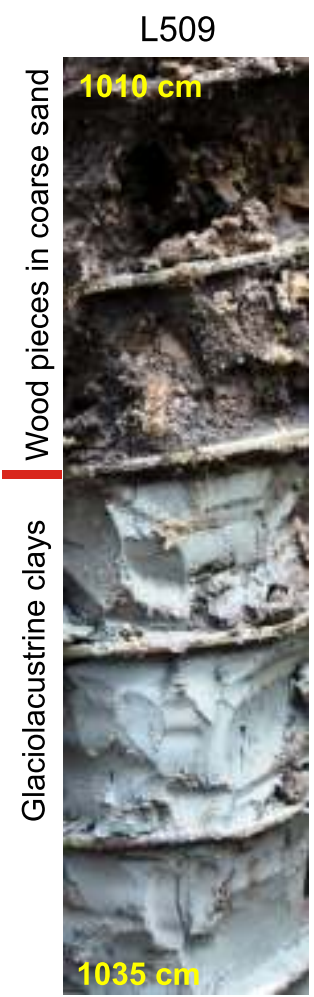

L522

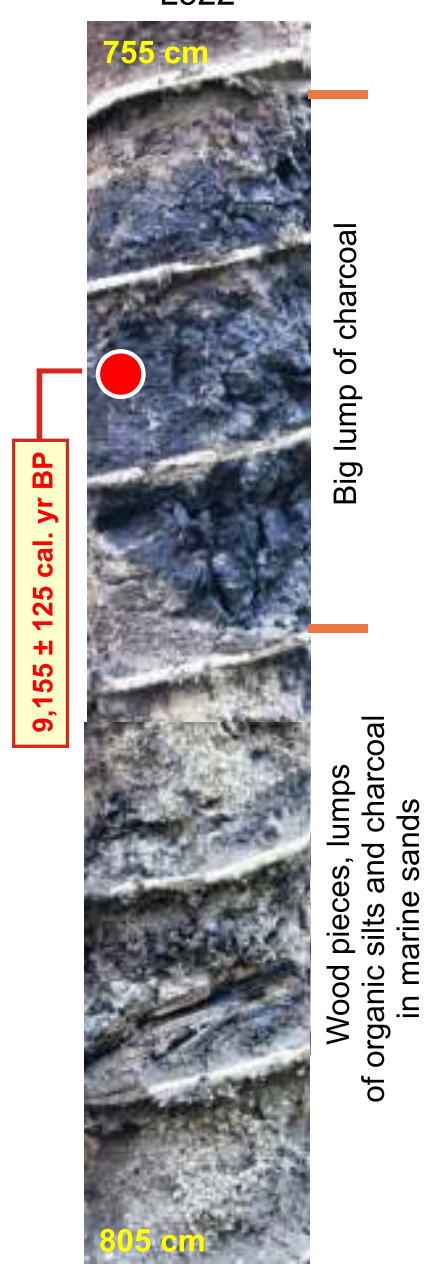

Fig. 13. The tsunami deposits at Rowy

The abundance of twigs, wood pieces, trunks and charcoal lumps in tsunami deposits is visible; the yellow numbers denote the depth below the ground surface

large sediment load carried by the waves caused the waves' velocity and transport capacity to decrease towards the south. As a result, the heavier components (shells) were deposited first, and the lighter fragments of wood and other plants reached further south.

Second, in places where the tsunami layer (TD) is thin, it is always massive; an example is the northern hollow. In places where it is thicker, its lower part is massive and its upper part is laminated (log L514; Fig. 14). The lamination probably formed during the terminal phase of inundation, when the wave energy dissipated, and it is the record of deposition from a waning current and probably, from backwash (Smith et al., 2007).

\section{GRAIN-SIZE DISTRIBUTION}

After removal of pebbles and organodetrital material, the tsunami deposits are composed of fine to medium quartz sand. The 43 sand samples collected from cores L424, L501, and L507 average 2.072 phi in diameter with a standard deviation of 0.467 phi. The sand is poorly to very poorly sorted (SD $\pm 1 \sigma$ :
$1.281 \pm 0.423$ phi; Fig. 15 and Table 2). The skewness of the grain-size distributions varies ( $S D \pm 1 \sigma: 0.752 \pm 1.481)$. The distributions range from coarse skewed $(-0.729)$ to very fine skewed (2.233). However, coarse skewed distributions dominate, suggesting that the sand has a marine origin (Friedman, 1961, 1967, 1979). Tsunami deposits often contain admixtures of coarse sand and silt. In many places within the tsunami layer, an upward-fining trend was observed (Fig. 15B, C), but a massive structure was equally common (Fig. 15A). Such features have been recorded in tsunami events around the world (Dawson, 1994; Hindson et al., 1996; Clague et al., 2000; Dawson and Shi, 2000; Goff et al., 2001; Peters et al., 2001; Hori et al., 2007; Jaffe and Gelfenbaum, 2007; Kortegas and Dawson, 2007; Moore et al., 2007; Peters et al., 2007; Choowong et al., 2008; Smith et al., 2007; Goff et al., 2010; Peterson and Cruikshank, 2011).

In some tsunami layers, pebbles with diameters between -1 and -6 phi (Fig. 15) have been found. They usually occur at the sole of the layer in sand mixed with numerous fragments of wood and branches, and the pebbles are trapped between these remnants in the middle part of the layer. In this case, the 

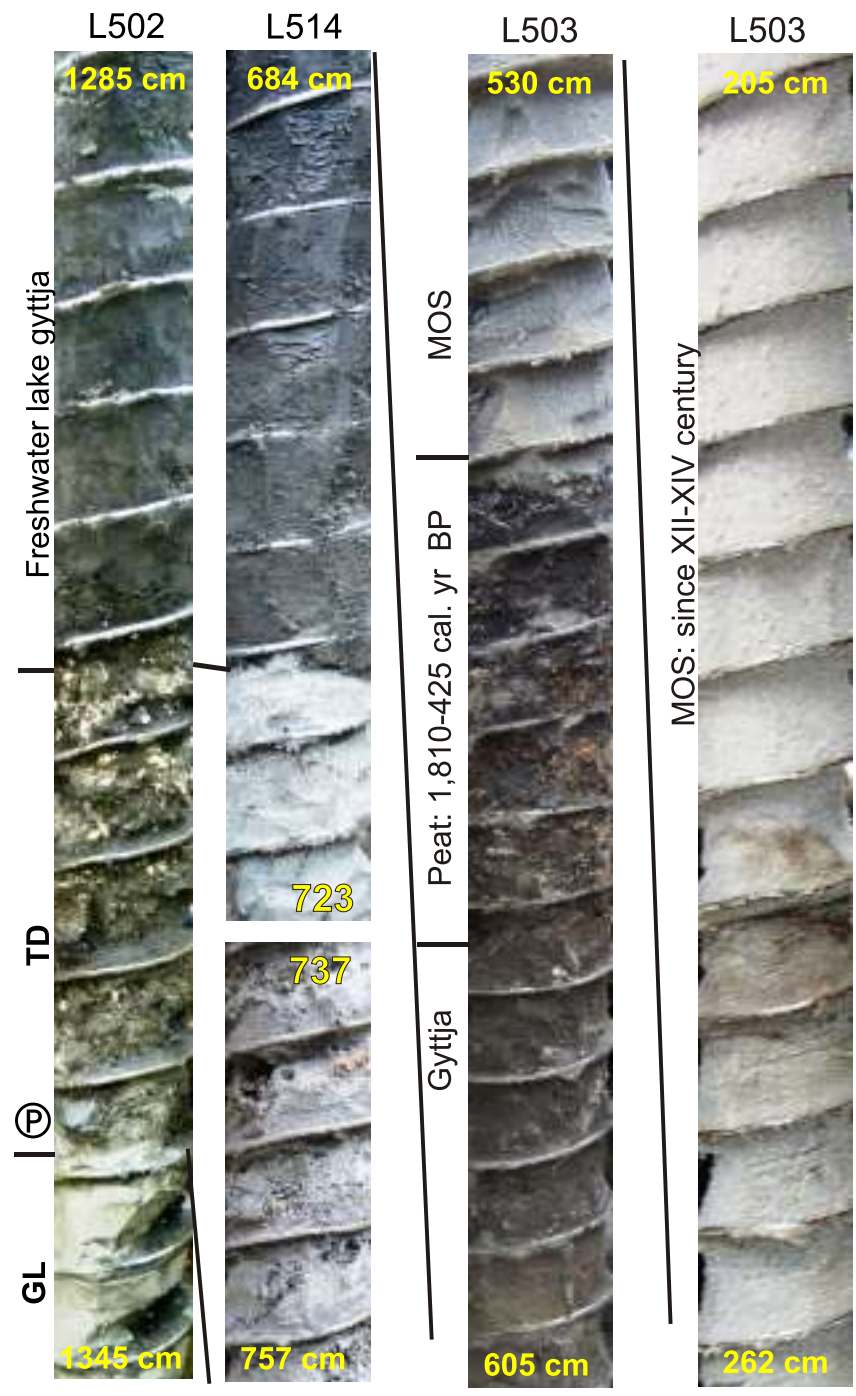

Fig. 14. Deposits overlying the tsunami deposits

GL - glaciolacustrine clays, P - pebbles, TD - tsunami deposits MOS - marine overwash sands; the rapid termination of the tsunam event is expressed by the sharp boundary between the tsunami deposits and the lacustrine gyttja shown in boreholes L502 and L514; the yellow numbers denote the depth below the ground surface

upward-fining trend of the grain-size is not observed, and the grain-size distribution is very fine skewed (>+1.30) (L507; Fig. $15 \mathrm{~A})$. The similarity matrices of grain size distributions constructed using the Kolmogorov-Smirnov test for three sediment logs show the lack of similarity of the tsunami deposits and Upper Holocene marine overwash sand (Fig. 15). This demonstrates the exceptional hydrodynamic conditions during the sedimentation of the event layer under discussion.

\section{ALLOCHTHONOUS BIOGENIC MATERIAL IN THE TSUNAMI DEPOSITS}

Tsunami deposits found at different sites around the world contain various biogenic remnants, such as marine, brackish and freshwater shells preserved in their entirety or in the form of debris (Moore and Moore, 1988; Hindson et al., 1996; Benson et al., 1997; Witter, 1999; Clague et al., 2000; Fujiwara et al., 2000; Goff et al., 2000, 2001, 2006, 2010; Hutchison et al., 2000; Bryant and Nott, 2001; Dominey-Howes et al., 2006; Dominey-Howes, 2007; Peters et al., 2007; Mamo et al., 2009; Engel and Brückner, 2011; Peterson and Cruikshank, 2011), valves of marine and brackish diatoms and other microfossils (Clague et al., 1994a, 2000; Hemphill-Haley, 1996; Witter, 1999; Dawson and Shi, 2000; Hutchinson et al., 2000; Goff et al., 2001, 2010; Peters et al., 2001; Schlichting and Peterson, 2006; Dominey-Howes, 2007; Nanayama et al., 2007; Kokociński et al., 2009; Engel and Brückner, 2011; Peterson and Cruikshank, 2011), and plant macrofossils (plant detritus, seeds, cones, bark, twigs, branches, and leaves; Clague and Bobrowsky, 1994a, b; Clague et al., 1994; Witter, 1999; Domniney-Howes et al., 2006; Peters et al., 2007; Goff et al., 2010). The tsunami deposits found at Rowy are also rich in a diverse and quantitatively large admixture of biogenic in content derived from marine, brackish and freshwater environments as well as from the terrestrial environment. These components are described below.

Shells and shell debris. Shells and shell debris occur in the tsunami layer found at Rowy in large quantities; for example, in part of sediment borehole L500, which is $0.7 \mathrm{~m}$ long and has a diameter of $8 \mathrm{~cm}, 1398$ specimens were identified (Table 3, Figs. 12 and 16). In total, 4068 specimens were separated from the deposits. A malacological analysis showed that the number of species in each sample varies from 1 to 4 , and the number of representatives of species in the samples varies from 21 to 391 in borehole L500. The assemblage of molluscs in the deposits is very poor in terms of species composition but contains species belonging to marine (M), brackish (B) and freshwater (S) environments. Marine species dominate most of the samples (Table 3); they include the bivalves Cerastoderma glaucum and Macoma balthica; the former is very common in the TD, and the latter is rare. The brackish species represented by gastropods Peringia ulvae (formerly Hydrobia ulvae) and Ventrosia ventrosa (formerly Hydrobia ventrosa) are in the minority (Table 3). Freshwater species occur sporadically and comprise two species of gastropods, Theodoxus fluviatilis and Valvata piscinalis and the bivalve Pisidium casertanum.

The shells collected were heavily damaged. Most of the samples contain shell debris (Figs. 12 and 16) which, using the procedure of Ložek (1964), was converted to whole mollusc specimens. Entire half-shells are in the minority, and only some specimens of whole shells were found. Their state of preservation indicates that the shells were redeposited from their primary environment. The abundance of the bivalve Cerastoderma glaucum within the tsunami layer also supports the idea of redeposition. The shell of this bivalve is relatively thick and resistant, and during transport, it breaks into fragments, unlike Mytilus trossulus (former Mytilus edulis) and Macoma balthica, the shells of which are fragile and usually become crushed while being redeposited. The size of $C$. glaucum, which is dominated by small specimens, suggests that they came from the shoreface, where they reproduce ( mudziński, 1982; Jagnow and Gosselck, 1987), and were redeposited on land during the rapid inundation of the Rowy Isthmus.

Plant macrofossils. Plant macrofossils are represented mainly by seeds (Fig. 17). The following plant genera and species were identified: Zannichellia palustris, Najas flexilis, Ruppia maritime, Schoenoplectus tabernaemontani, Sch. lacustris/tabernaemontani (bulrush Tabernaemontani, Scirpus tabernaemontani), Bolboschoenus maritimus, and Chenopodium. Most of the goose-foot taxa (Chenopodium) are aquatic 
A

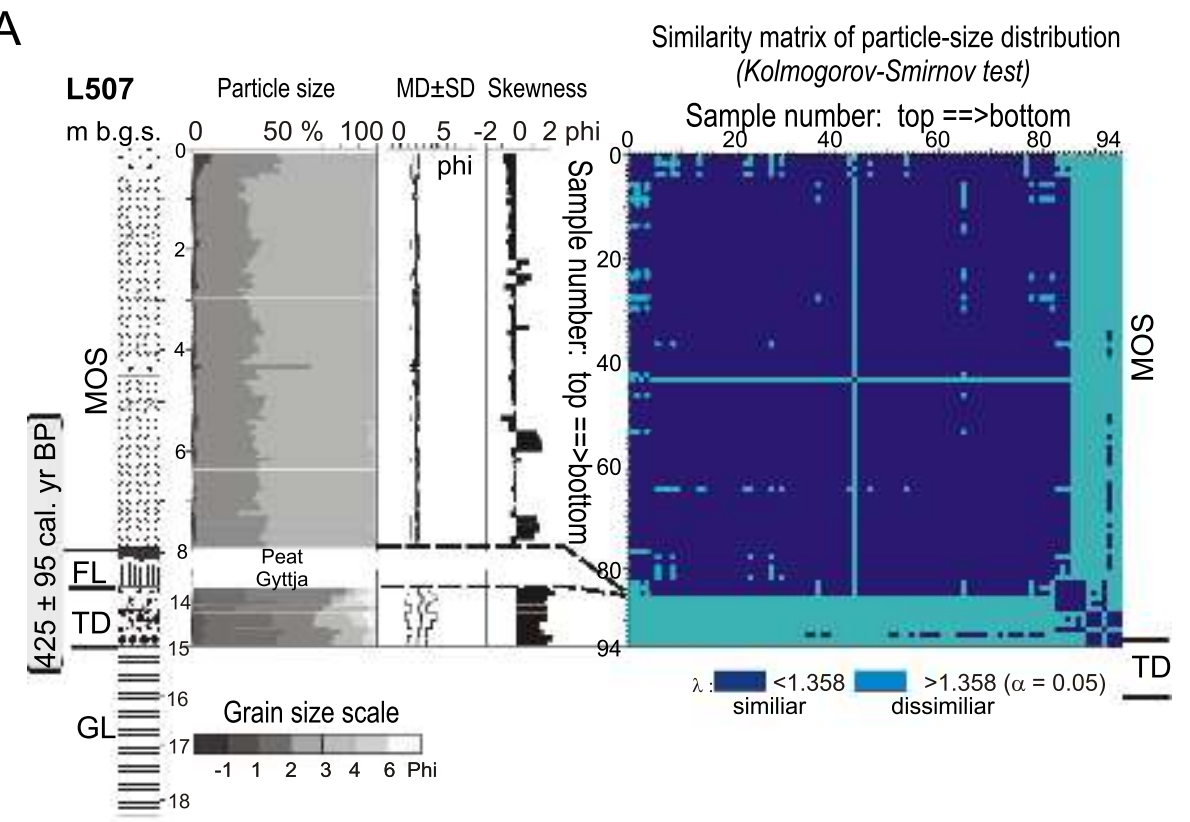

B
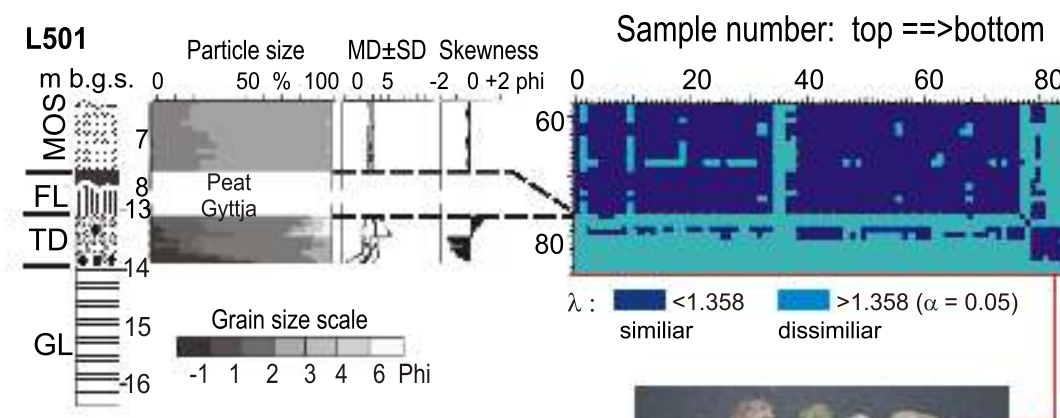

Pebbles from the tsunami deposits

C

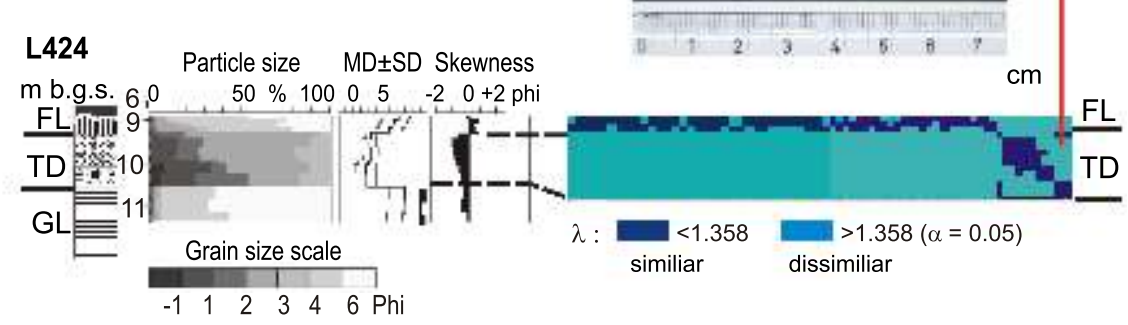

Fig. 15. A comparison of the particle size characteristics of the tsunami deposits (TD) and the marine overwash sand (MOS) deposited during the last several centuries

The similarity matricies of the grain-size distributions highlight the dissimilarity of these deposits

plants that colonize - among others - brackish environments. In particular, the dominance of ruppia (Ruppia maritima) is an additional sign that the test material was derived from the shoreface zone on land.
Marine diatoms. Diatom analysis was performed on the deposits from sediment log L424 (M. Lutyńska in Rotnicki et al., 2009). A relatively well-preserved diatom flora was found at a depth of 9.30-9.90 m b.g.s. in the upper part of the tsunami layer, which was composed of medium sand. The following dia- 
Logarithmic moment measures (phi scale) of tsunami deposits (TD) compared with the same measures of the Upper Holocene marine overwash sands (MOS) at the Rowy site

\begin{tabular}{|c|c|c|c|c|}
\hline Type of deposits & $\begin{array}{l}\text { Number of } \\
\text { samples }\end{array}$ & $\begin{array}{c}\text { Mean diameter (1st measure) } \\
\text { and its dispersion } \\
(\mathrm{Md} \pm 1 \mathrm{~s})\end{array}$ & $\begin{array}{l}\text { Standard deviation - sorting } \\
\text { (2nd measure) and its dispersion } \\
(\mathrm{SD} \pm 1 \sigma)\end{array}$ & $\begin{array}{l}\text { Skewness (3rd measure) } \\
\text { and its dispersion } \\
(\text { Sk } \pm 1 \sigma)\end{array}$ \\
\hline $\begin{array}{l}\text { Tsunami sands } \\
\text { - Middle Holocene }\end{array}$ & 43 & $\begin{array}{c}2.072 \pm 0.467 \\
\text { (without pebbles) }\end{array}$ & $1.281 \pm 0.423$ & $0.752 \pm 1.481$ \\
\hline $\begin{array}{l}\text { Marine overwash sands - } \\
\text { Upper Holocene } \\
\text { (century-scale interval) }\end{array}$ & 185 & $1.891 \pm 0.102$ & $0.424 \pm 0.084$ & $-0.253 \pm 0.448$ \\
\hline
\end{tabular}
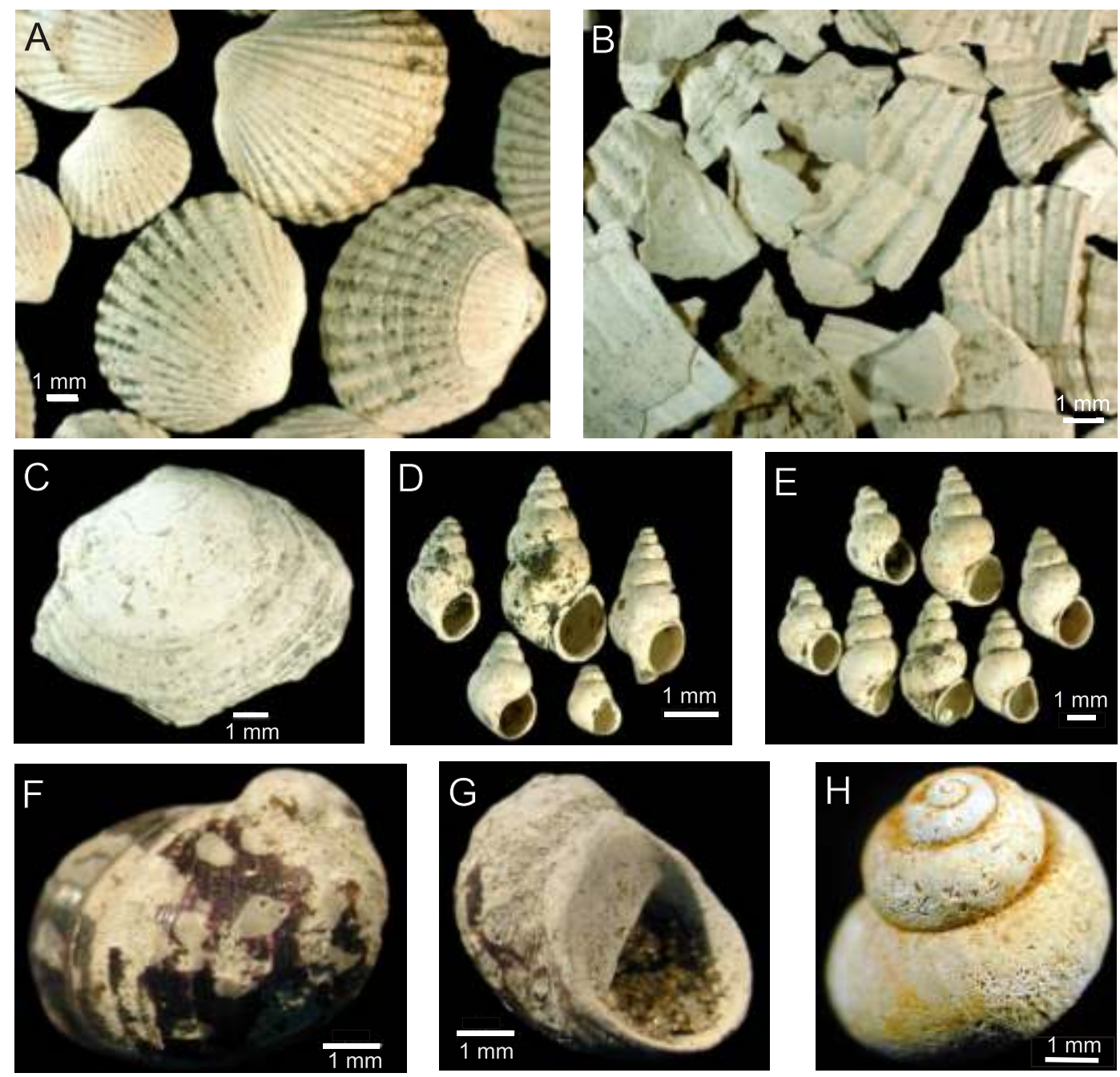

Fig. 16. Species of marine bivalves and brackish and freshwater gastropods found in the tsunami deposits at Rowy

A - Cerastoderma glaucum, B - debris of Cerastoderma glaucum, C - Macoma balthica,

D - Peringia ulvae (formerly Hydrobia ulvae), E - Ventrosa ventrosa (formerly Hydrobia ventrosa),

$\mathbf{F}, \mathbf{G}-$ Teodoxus fluviatilis, $\mathbf{H}$ - Valvata piscinalis 
Composition of malacofauna in tsunami deposits at the Rowy site

\begin{tabular}{|l|c|c|c|c|c|c|c|c|}
\hline \multirow{2}{*}{ Borehole } & \multirow{2}{*}{$\begin{array}{c}\text { Amount of } \\
\text { samples }\end{array}$} & \multirow{2}{*}{$\begin{array}{c}\text { Depth } \\
{[\mathrm{m}]}\end{array}$} & \multirow{2}{*}{$\begin{array}{c}\text { Total number } \\
\text { of speciments }\end{array}$} & & \multicolumn{5}{|c|}{ Environment of species } \\
\cline { 5 - 9 } & & & $\begin{array}{c}\text { Cerastoderma } \\
\text { glaucum }\end{array}$ & $\begin{array}{c}\text { Macoma } \\
\text { balthica }\end{array}$ & $\begin{array}{c}\text { Peringia } \\
\text { ulvae }\end{array}$ & $\begin{array}{c}\text { Ventrosia } \\
\text { ventrosa }\end{array}$ & $\begin{array}{c}\text { Teodoxus } \\
\text { fluviatilis }\end{array}$ \\
\hline L500 & 11 & $9.25-9.85$ & 1398 & 1167 & 13 & 83 & 134 & 1 \\
\hline L501 & 14 & $13.1-13.8$ & 479 & 465 & - & 2 & 9 & 3 \\
\hline L504 & 16 & $9.5-10.3$ & 1061 & 959 & - & 45 & 55 & - \\
\hline L507 & 16 & $11.5-12.4$ & 1130 & 951 & 1 & 47 & 128 & 3 \\
\hline & \multicolumn{2}{|c|}{ Total } & 4068 & 3542 & 14 & 177 & 326 & 7 \\
\hline
\end{tabular}

1) - former: Hydrobia ulvae; ${ }^{2)}$ - former: Hydrobia ventrosa
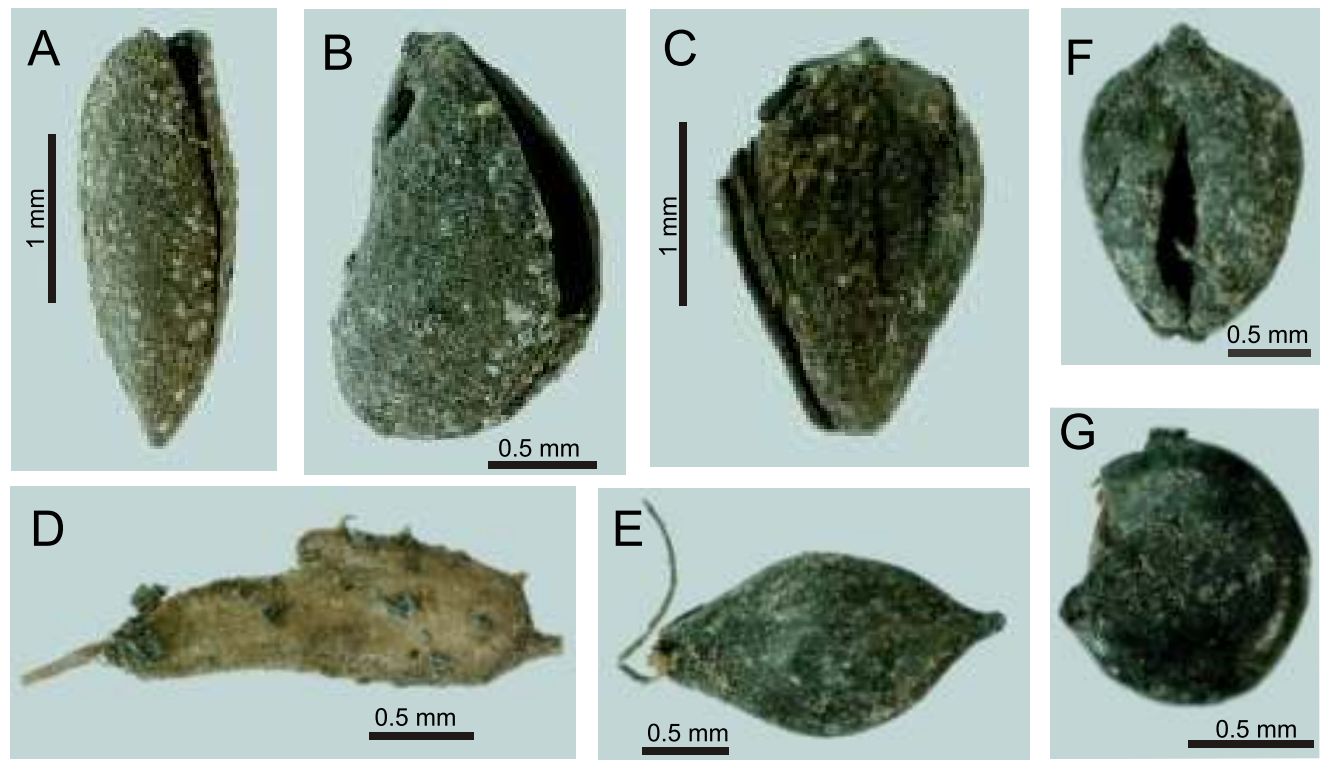

Fig. 17. Plant macrofossils (seeds) found in the tsunami deposits at Rowy

A - Najas flexilis, B - Ruppia maritime, C - Bolboschoenus maritimus, D - Zannichellia palustris, E - Schoenoplectus tabernaemontani, F - Sch. lacustris/tabernaemontani, G - Chenopodium spp.

toms were identified: Amphora acutiuscula, Catenula adherent, Cocconeis hofmanii, Co. scutellum, Co. peltoides, Dimerogramma minor, Diuploneis smithii and Grammatophora marina. Quantitatively, the diatom assemblage is dominated by brackish specimens; their content varies between 53.1 and $73.2 \%$. Marine diatoms constitute 3\%.

\section{DEPOSITS OVERLYING THE TSUNAMI LAYER}

The tsunami deposits are overlain by freshwater lake gyttja the thickness of which varies from $7.55 \mathrm{~m}$ in the central parts of the fossil hollows to $2.75 \mathrm{~m}$ in the saddle between the hollows. A sharp boundary between the tsunami deposits and the overly- ing gyttja (L502, L514; Fig. 14) suggests the abrupt termination of an extreme event followed by the formation of freshwater lakes within the hemispherical hollows. Individual shells of Cerastoderma glaucum found in the gyttja provided evidence of rare marine incursions into the lake. Over time, due to gyttja deposition, the lake became shallow and evolved into a peat bog. The lake existed for ca. 5,000 years. The lowermost part of the gyttja layer is 6,600 \pm 130 cal. yr BP old (Gd-7018, Gd-15703), while the oldest peat overlying the gyttja dates from 1,745 \pm 115 cal. yr BP (Poz-49607) and 1,450 \pm 150 cal. yr BP (Gd-15708) (Table 1; Figs. 8 and 9).

In the final stage of peat formation but before the accumulation of marine barrier sand, which began approximately 450 years BP (Rotnicki et al., 2009b), the primary thickness of the gyttja, prior to its compaction, was greater than $12 \mathrm{~m}$ in the deepest parts of the Rowy Isthmus (Fig. 8; Rotnicki, 2008, 


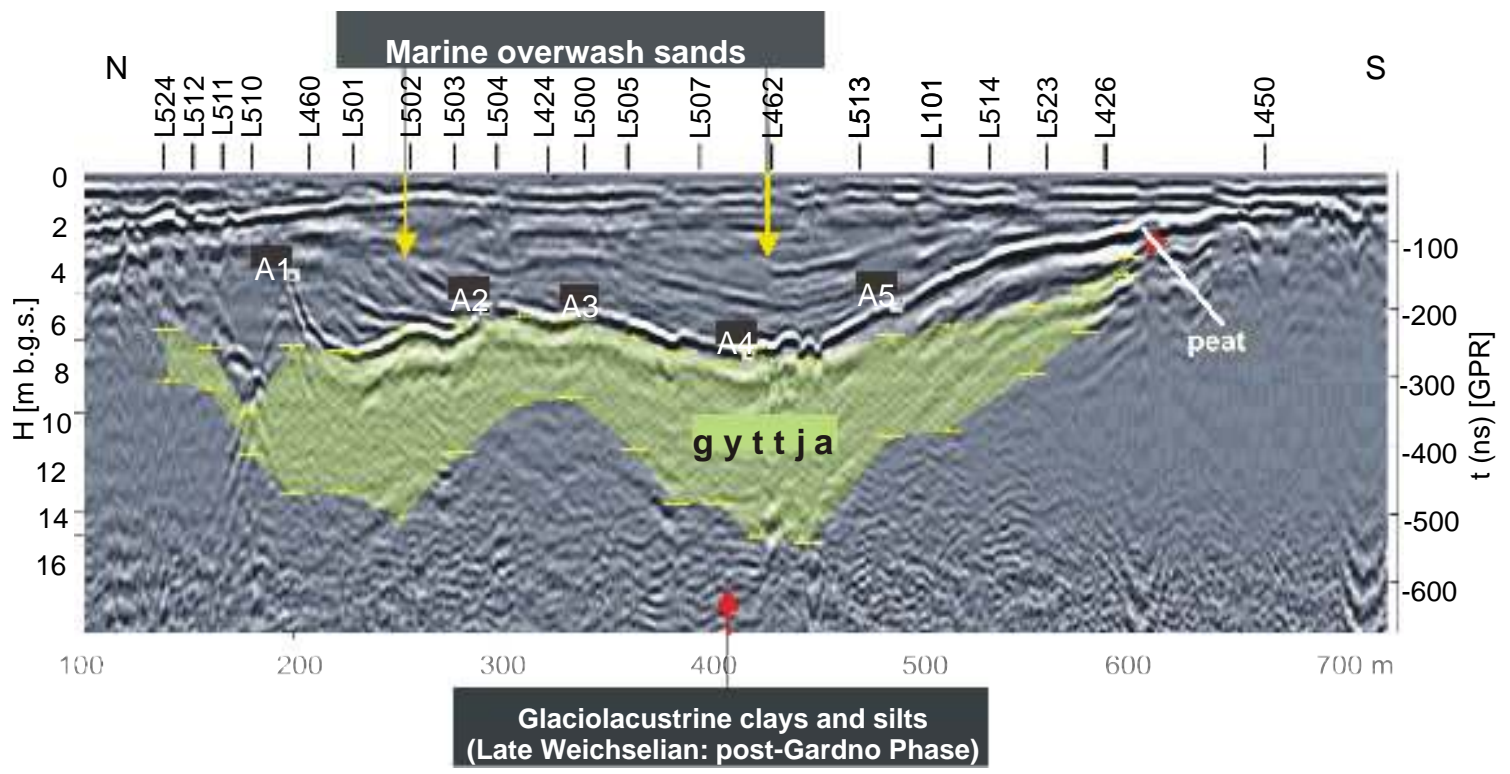

Fig. 18. A ground-penetrating radar profile (GPR) - a meridional cross-section through the Rowy Isthmus

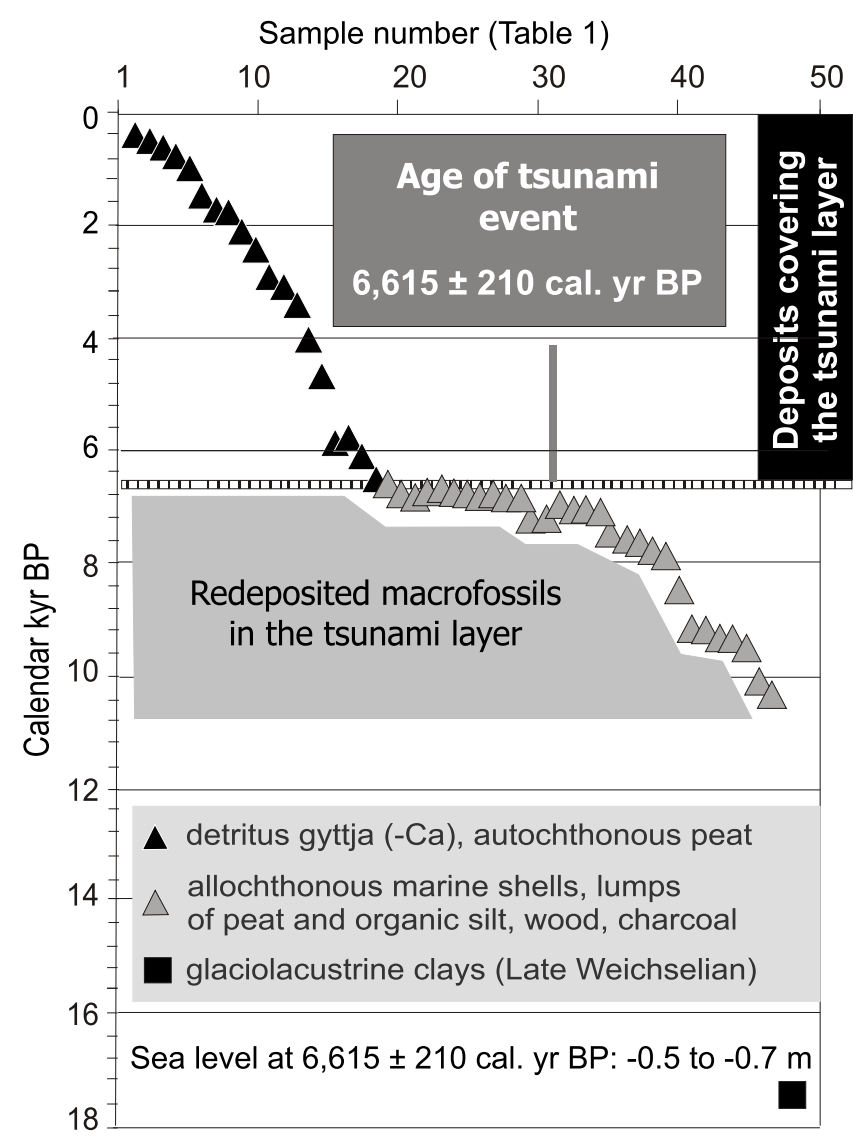

Fig. 19. The age of the tsunami event
2009). The surfaces of the peat deposits before compaction was at an ordinate of between $1.3 \mathrm{~m}$ a.s.l. and $0.8 \mathrm{~m}$ b.s.l. compared to the present-day sea level (the red dotted line in Fig. 8) and at elevations of $2.3 \mathrm{~m}$ and $0.2 \mathrm{~m}$ a.s.I. in relation to the sea level before 400-600 years ago, when peat formation ceased. At that time, the sea level was approximately $1 \mathrm{~m}$ lower than it is today (Rotnicki, 2009).

The deposition of marine overwash sand on the peat and gyttja caused their gradual compaction and decreased their thickness, which led to changes in the elevations of their sole and ceiling (Figs. 8 and 9). Positive feedback between the sedimentation of marine sand on the peat plain and the compaction of underlying gyttja and peat allowed a $7 \mathrm{~m}$ thick succession of MOS to accumulate in a short period of $400-500$ years during the Little Ice Age (LIA). Its internal structure (cross-bedding) is very distinct in the GPR profiles (Fig. 18). MOS is composed of medium quartz sand (1.891 \pm 0.102 phi), which is well-sorted (SD $\pm 1 \sigma$ : $0.424 \pm 0.087 \mathrm{phi})$. The grain-size distribution ranges from coarse skewed to symmetrical (Sk $\pm 1 \sigma:-0.253 \pm 0.448$; Table 2 ). All of the sand succession is relatively homogeneous (Fig. 15A, B). In the past 100-200 years MOS has undergone intensive aeolian reworking and this resulted in the development of dunes. The surface of the sand barrier - outside the dune field - is currently at an ordinate of 2.0-3.0 $\mathrm{m}$ a.s.l.

Due to the time span of several hundred years since the MOS accumulated, its deposition was probably caused not only by ordinary storm surges but also by high, extremely energetic surges with a recurrence interval of between 100 and 500 years. Comparing the relatively uniform effects of these storm surges with the event that caused the deposition of the TD in the hollows, it is obvious that the energy of these events must have been very different (Fig. 15). 


\section{AGE OF THE TSUNAMI EVENT} AND OF THE FOSSIL HOLLOWS

The tsunami event was dated using the following procedure. A total of 49 radiocarbon dates were used. Six of them determined the ages of in situ deposits that were older than the event layer and twenty determined the ages of deposits younger than this layer. A total of 23 dates were obtained from biogenic material found in the tsunami layer. The youngest date obtained from a peat sample that was older than the TD was $7,290 \pm 120$ cal. yr BP (L173 in Fig. 9 and Table 1), and therefore, the tsunami event occurred after that date. The ages of the redeposited biofossils collected from the event layer vary between 10,390 \pm 130 (a piece of wood) and 6,630 $\pm 130 \mathrm{cal}$. yr BP (a lump of peat) (Table 1: samples 49 and 21 , respectively). The oldest in situ layer built of calcareous free detritus gyttja overlying the TD was dated to $6,600 \pm 220$ cal. yr BP (Table 1: sample 20; Fig. 8). Therefore, the tsunami event occurred between the last two dates, i.e., between 6,600 and 6,630 cal. yr BP, with an accuracy of several decades (Fig. 19).

The fossil hollows must have been nearly synchronous with the tsunami deposition. The idea that these were glacial kettle holes must be firmly rejected for several reasons. First, the glaciolacustrine clays covering the glacial till of the Gardno Phase were dated to 17,000-18,000 cal. yr BP (Table 1, date 49; borehole 101 in Figure 8; Rotnicki and Borówka, 1995; Rotnicki, 2001). Secondly, sedimentation in the ice-dammed lake was terminated by the deposition of glaciofluvial sands and gravels when the ice margin was situated north of the Rowy Isthmus; such conditions were not for favourable to the occurrence of dead ice blocks. Thirdly, buried dead ice melted during the Allerød Interstage (Kozarski, 1963). In many glacial tunnel valleys the Late Weichselian peat was originally deposited on the dead ice. As the ice melted, the accumulation of lake gyttja on the peat began (Wojciechowski, 2000). At Rowy, the time span between the recession of the last ice sheet and the tsunami event is 7,000-8,000 years and it is impossible that the hollows survived without the deposition of any type of sediment.

\section{CAUSE OF THE TSUNAMI EVENT - DISCUSSION}

The deposition of marine sand containing a large amount of organodetrital material, including shells (mainly Cerastoderma sp.) and shell detritus, rip-up clasts of peat, organic silt and glaciolacustrine clays, large pieces of charcoal, and tree branches and trunks, which covers a time span of 3,690 cal. yr (its age is between 10,385 \pm 135 and 6,630 \pm 130 cal. yr BP), probably resulted from an extremely high-energy event with a very low probability of occurrence. The allochthonous material deposited within the marine sand came from different sedimentary environments - starting from the marine shoreface and ending with terrestrial environments (lacustrine, marsh, peat and forest). Clasts of peat, branches, trunks and charcoal originated in an Early Holocene terrestrial environment, which was then present far to the north of the present-day coastline (Uścinowicz, 2003, 2006). Therefore, during the extreme event under discussion, strong sea waves could have eroded this organodetrital material from the land, and they might have caused the terrestrial deposits present beneath the shoreface to be exhumed and to serve as a source of such material.
The deposition of marine sand mixed with abundant shell detritus was rapid. The poor sorting of the sand, the lack of lamination and the fining-upward sequences found within the event layer in some cores support this manner of sedimentation in the hemispherical hollows. The relatively large thickness of the tsunami deposits $(1-3 \mathrm{~m})$ probably resulted from their accumulation in hollows without outlets in which the tsunami waves abruptly lost their energy.

The geological record shows no evidence of the presence of a Holocene sea in the area prior to the event under discussion (Rotnicki, 2009; Rotnicki et al., 2009b). On the other hand, farther south, tsunami deposits were found beneath the gyttja of Gardno Lake, which is approximately $2 \mathrm{~km}$ south of the present Baltic shoreline (core Ga3/02 after Lutyńska, 2008; Figs. 4 and 8). It is not known how far from this place the coastline was at that time, but there is evidence that the mean sea level was $50-70 \mathrm{~cm}$ lower during the event than it is today (Rotnicki, 2009). Because the top surface of the glaciofluvial sand and gravel outside the fossil hollows lies at an elevation of 0-2 $\mathrm{m}$ a.s.I., it can be assumed that the run-up of the tsunami waves occurred on surfaces that were $0.5-2.7 \mathrm{~m}$ a.s.l. at that time. By considering the extent of tsunami flooding and the land elevation, it can be concluded - according to Lowe and de Lange (2000) and Dawson and Stewart (2007) - that the height of the run-up reached at least $5 \mathrm{~m}$ above the ground surface.

The causes of the tsunami event are unknown and they may be considered only in terms of probable hypotheses. In addition, a tsunami does not explain the genesis of the hemispherical hollows at Rowy by itself. Around the world, tsunami events along flat coastal lowlands have been recorded as thin layers of sand up to $0.5 \mathrm{~m}$ thick that extended between several hundred metres and several kilometres inland (Hindson et al., 1996; Benson et al., 1997; Clague et al., 2000; Dawson and Shi, 2000; Goff et al., 2000, 2010; Smoot et al., 2000; Bryant and Nott, 2001; Scheffers and Kelletat, 2003; Jaffe and Gelfenbaum, 2007; Morton et al., 2007; Abrantes et al., 2008; Choowong et al., 2008; Peterson et al., 2008; Fujino et al., 2008; Peterson and Cruikshank, 2011; Peterson et al., 2013). The sand came from the erosion of a relatively narrow nearshore and beach zone (Dawson, 1994; Jaffe and Gelfenbaum, 2007; Morton et al., 2007) and covered the mantle relief, which showed no signs of erosional unconformity at its base (Dominey-Howes et al., 2006; Dominey-Howes, 2007; Choowong et al., 2008; Szczuciński, 2008; Piotrowski et al., 2013).

Distinct erosional forms usually form along rocky cliff coasts and headlands. They encompass zones of abrasion ramps and cliffs, whereas boulders are transported and deposited along the tops of cliffs (Young and Bryant, 1992; Bryant and Nott, 2001). Rectangular depressions up to 1-1.5 m deep the sides of which are a few tens of metres in length are characteristic of rocky platforms. Their shapes are determined by joint and bedding planes. The bottoms of such depressions and abrasion ramps are often fluted (Young and Bryant, 1992). Other erosional forms include canyons, drill holes and potholes. The diameter of the latter is $30-40 \mathrm{~m}$, and the depth is $1.0-1.5 \mathrm{~m}$ (Young and Bryant, 1992; Bryant and Nott, 2001).

There are no known examples of the deep erosional activity of tsunami waves in flat lowland areas a few hundred metres from the shoreline. In addition, it is unlikely that tsunami waves overloaded with a highly concentrated bed and a suspended load in the form of tree branches and trunks, pebbles, shells and sand were capable of eroding the floor to a depth of $12-14 \mathrm{~m}$. 
The most likely hypothesis that explains the cause of the tsunami event and the genesis of the fossil hollows considers both meteorite impacts and tsunami waves. Meteorite falls in the Southern Baltic and Polish Lowland are not unusual and occurred several times in the Middle Holocene. They resulted in the formation of craters, which are still well-preserved. Examples of such craters include the Kaali craters on Saaremaa Island (Raukas et al., 1999), the llumetsa craters in south-east Estonia (Raukas et al., 2001) and several craters at Morasko near Poznań (Stankowski, 2010). The questions arises how big an impactor was to generate the tsunami wave and what was the tsunami amplitude.

However, the hypothesis of meteorite impacts and tsunami waves at Rowy explains in the fullest possible way both the deposition of the event layer and the formation of the hollows in which it was found. The event might have occurred as follows. A few meteorites fell in the coastal zone. Some hit the land and formed craters, and others fell into the Baltic Sea, causing huge waves that eroded the shoreface and redeposited material from this zone (mainly littoral sand with marine shells as well as older, Lower Holocene terrestrial deposits) on, including in the newly formed craters. Modelling the relationship of crater diameter on the land to the diameter of the asteroid shows that the ratio varies between 1:20 and 1:24 (Kring, 1997; Hills and Goda, 1998). Taking into account the dimension of the bowl-shaped hollows at Rowy the meteorite was 8-12 m in diameter. However, this is a very rough estimation. According to Shoemaker et al. (2005) estimation of the dimension of the meteorite that formed a crater is very difficult because it depends not only on the size of a meteorite but also on the impact velocity and angle. The depth and diameter of the hollows at Rowy are similar to the parameters of small Middle Holocene meteorite craters found in Estonia and Poland that were noted above (Raukas et al., 1999, 2001; Stankowski, 2010). However, the craters at Rowy were remodelled just after their formation by tsunami waves. The determination of the dimensions and site of the meteorite/meteorites fall into shallow nearshore water of the Baltic Sea is now impossible. In the case of shallow-water impact, the mass of ejected material consisting of water and sediments from the sea-floor dominates over the mass of water displaced from the transient crater formed in the water column (Wünnemann and Wiess, 2015). The sedimentological features of the event layer at Rowy support the supposition that tsunami waves were overloaded with material from the substratum.

It is also probable that the craters at Rowy originated in an explosion and that tsunami waves were also generated by this explosion. This hypothesis explains not only the existence of the hollows themselves but also the presence of marine sand containing shells and detritus of Cerastoderma sp., lumps of peat, tree trunks and branches, and lumps of charred wood at their bottoms. The impact of a meteorite is recognized as one of the causes of tsunamis (Bryant, 2008; Perkins, 2009, Wünnemann and Weiss, 2015). Massel (2012) showed theoretically that the impact of a small meteorite with a diameter of several metres on the shallow sea water of a coastal zone can cause a tsunami and Nemtschinov et al. (1997) estimated that the probability of a meteorite with a radius of around $5 \mathrm{~m}$ impacting the Earth is large at $50 \%$ per annum per the whole Earth surface (Fig. 20).

To test the hypothesis of meteorite impact, the assemblage of grains of magnetic minerals (with diameters of 2-3 phi) separated from the tsunami deposits in the deepest parts of the hollows was analysed to determine its content of extraterrestrial matter. A total of 191 analyses of the chemical composition of 113 grains separated from 23 samples from the microarea with high magnetic susceptibilities were performed. However, no spherules composed of iron and nickel were found; therefore, no evidence of an extraterrestrial origin for these grains was found. Most of the spherical grains consisted of compounds of either iron (magnetite-hematite) or iron and titanium (titanomagnetite). High nickel, chromium and titanium contents in the presence of iron were established in a few grains collected from sample no. L517/22. The shapes of the nickel-bearing grains were usually irregular; they may be components of erratic mafic rocks from Scandinavia. The increased magnetic susceptibility of some samples resulted from their high iron contents, which either formed minerals or was a component of the silicates and aluminosilicates present. The only spherule that had an almost perfectly smooth surface composed of pure iron was found in the tsunami deposit in sediment log L462 during the initial phase of research (Rotnicki et al., 2009).

However, the hypothesis of meteorite impacts followed by tsunami waves (with both impact craters and explosive craters), explains the paucity or lack of a mineralogical record of extraterrestrial material in the event layer on the bottoms of the fossil hollows. There are known impact craters that are full of sedi-

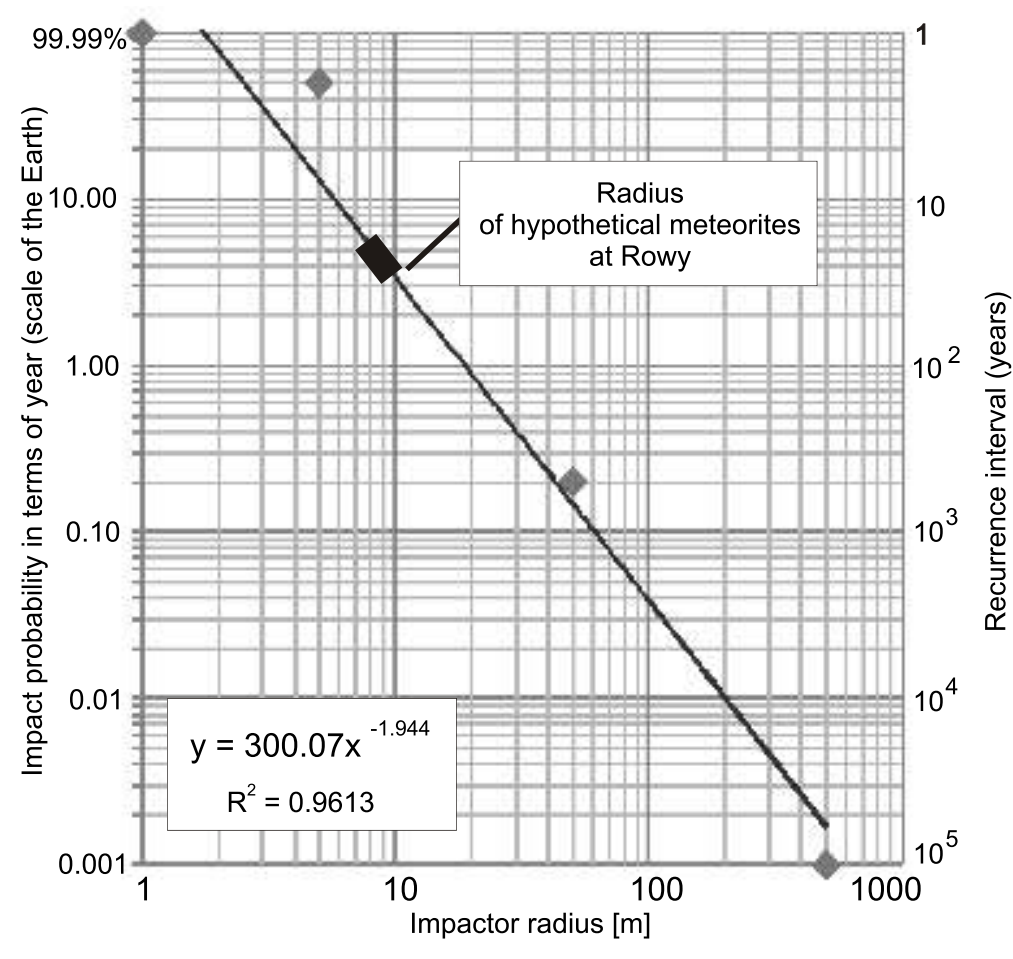

Fig. 20. Probability distribution (in terms of years) of the impacts of meteorites with various radii (based on data from Massel, 2012)

Black rectangle marks the probable range of the radius of meteorites that fell at Rowy 
ments that do not contain extraterrestrial matter, such as the craters formed by the fall of the iron meteorite "Morasko" near Poznań, Poland, during the Middle Holocene (Stankowski, 2010). Where it landed, there are several craters without rims that are similar in size to the fossil hollows at Rowy. Extraterrestrial material was found in the area adjacent to the craters. These are lumps of iron weighing up to $300 \mathrm{~kg}$ found at depths of up to $218 \mathrm{~cm}$ (Muszyński et al., 2012a, b) and surrounded by silty fine sand containing with iron microspherules similar to those found on the bottom of one of the fossil hollows at Rowy. The chemical compositions of the spherules found at Rowy and at Morasko are almost identical (Fig. 21; Stankowski et al., 2006; Stankowski, 2010; Muszyński et al., 2012a, b). At Rowy, the extraterrestrial matter could have been widely scattered by tsunami waves, which could also have modified the hypothetical craters that remain today at a depth of several metres. Therefore, the chance of finding such matter is small.

\section{REORGANIZATION OF THE COASTAL AREA WITHIN THE GARDNO-ŁEBA COASTAL PLAIN CAUSED BY THE TSUNAMI EVENT THAT WAS PROBABLY CAUSED BY METEORITE IMPACT}

It is important to note that tsunami events usually cause large-scale geomorphological changes in coastal areas (Dawson, 1994; Bryant et al., 1996; Bryant and Nott, 2001; Scheffers and Kelletat, 2003; Peters et al., 2007). There is evidence that the topography of the coastal zone in the Gardno-Łeba lowland and the geological architecture and hydrographic relations in the Rowy Isthmus changed significantly due to the tsunami event. During this event, the Rowy Isthmus constituted part of the flat and slightly undulating surface of the Pleistocene plateau. A meteorite impact caused the formation of hemispherical hollows, which were then flooded by tsunami waves. Nearly simultaneously, the sediment load they carried was dumped. A lake formed in the hollows. Its depth was 14-16 m in relation to what was then the topographic surface (Fig. 22).

The tsunami also inundated the large peatbog that spread as far south as the push moraine of the Gardno Phase (Fig. $22 \mathrm{~A}$ ), causing the formation of a large shallow lake that was initially connected with the hemispherical hollows (Fig. 22B) at approximately $6,600-6,670 \mathrm{cal}$. yr BP. The lake was occasionally connected with the Baltic Sea. Over time, the lake became shallower, and the sedimentation of gyttja terminated approximately $1,500 \mathrm{cal}$. yr BP. The peat bog that developed in this place existed for ca. 1,000 years. During the Little Ice Age (XIII-XVIII centuries), marine overwash sand began to accumulate (Fig. 22C). Storm surges caused the peat bog in the Rowy Isthmus to become inundated and the initial sandy barrier to form. The deposition of a large volume of sand resulted in compaction of the underlying gyttja and peat. Their original thickness was reduced by ca. $50 \%$. In the last 100-150 years, the sandy barrier was moulded by aeolian processes, and sand dunes $>10$ metres high developed (Fig. 22D).

The tsunami deposits that fill the hemispherical hollows date to $6,615 \pm 130 \mathrm{cal}$. yr BP and constitute the present geological
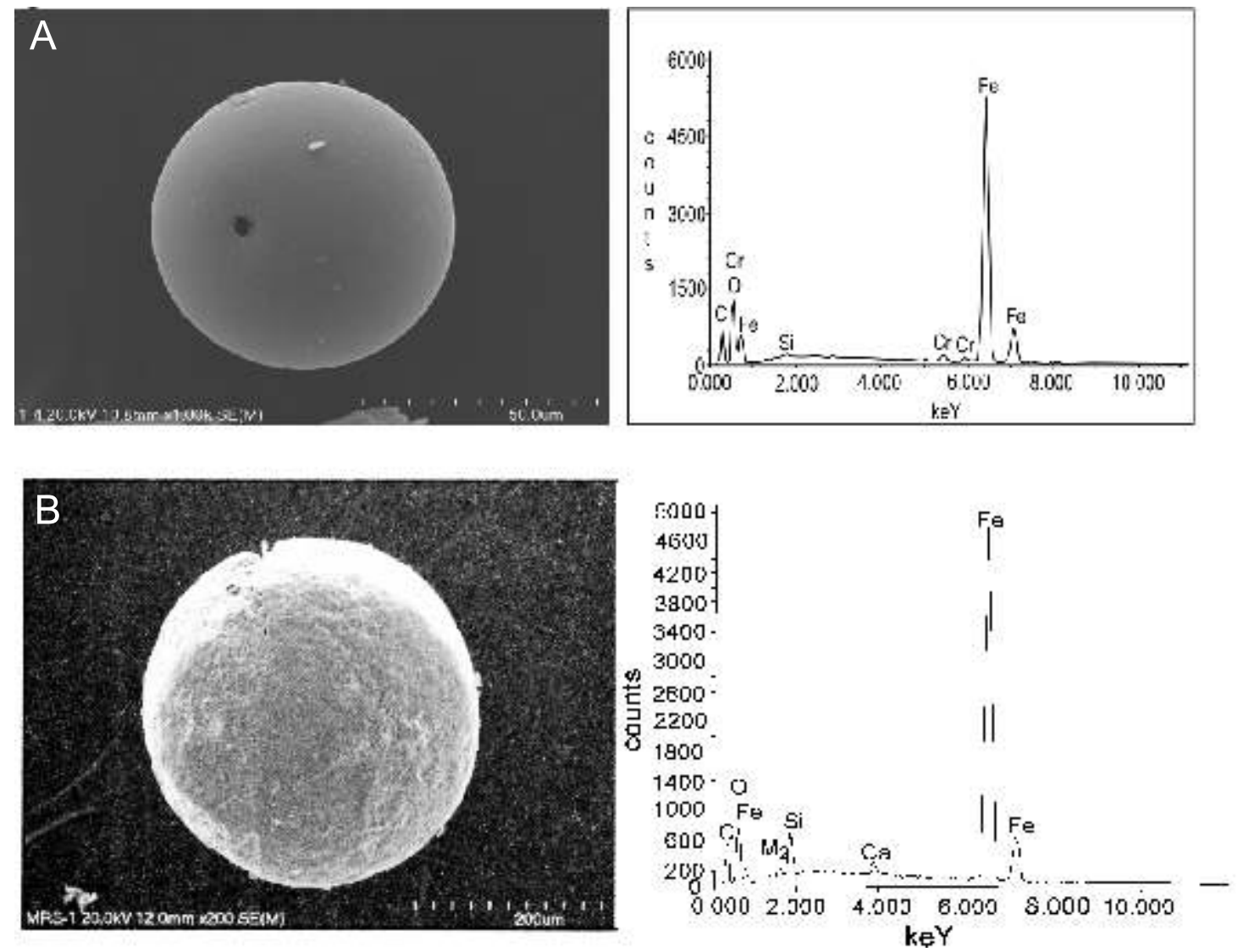

Fig. 21. Magnetic microspherules from the lowermost part of the tsunami layer found on the bottom of fossil hemispherical hollow (A) at Rowy (after Rotnicki et al., 2009) and from the place near Poznan where the meteorite called "Morasko" fell (B) (after Stankowski, 2010) 
A
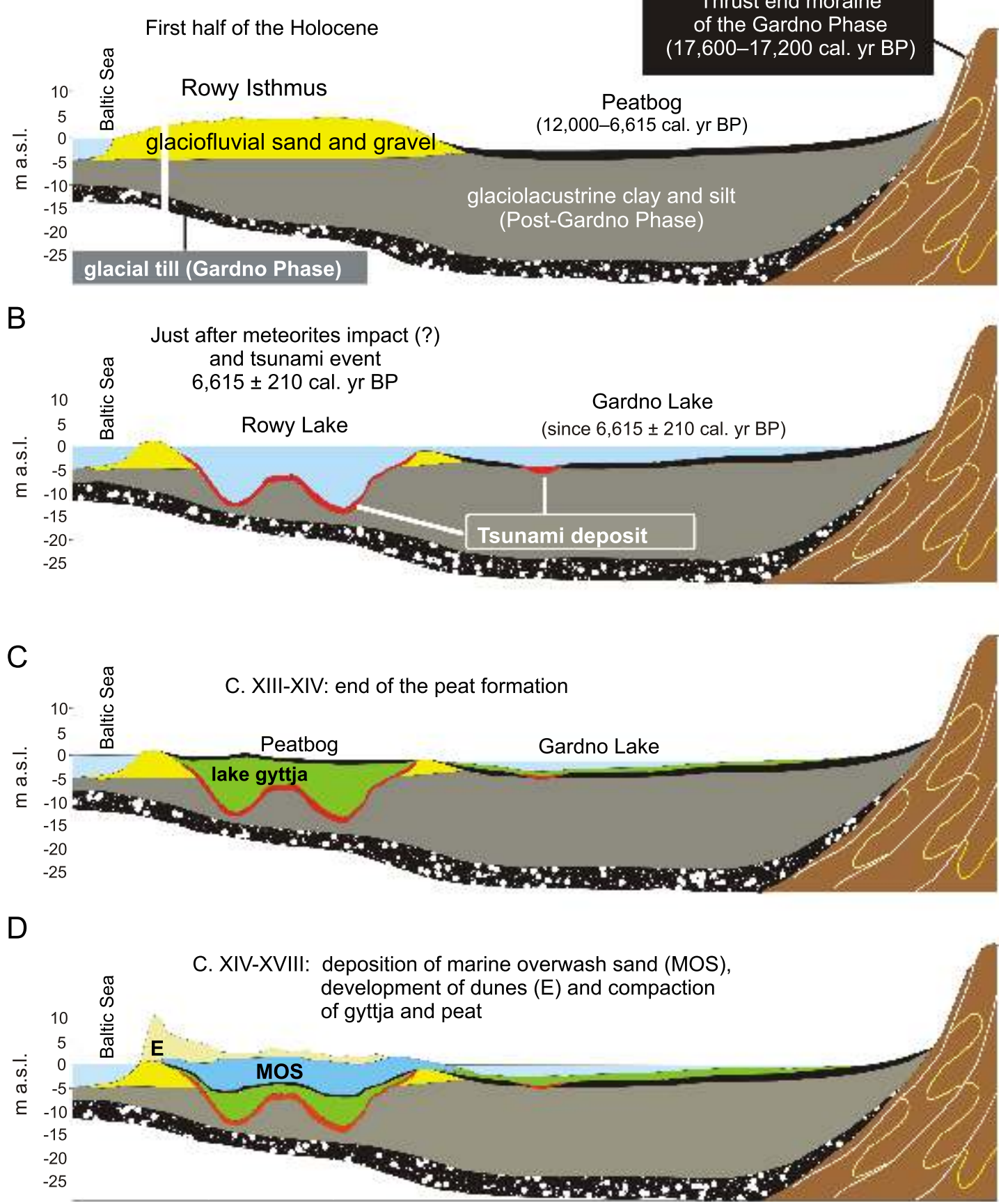

Fig. 22. The reorganization of the coastal zone at Rowy caused by the tsunami

record of the past event. While the sedimentological features of these deposits seem to indicate their tsunami origin, the genesis of the fossil hollows remains only a hypothesis that infers a meteorite impact. This is the first prehistoric tsunami documented on the southern coast of the Baltic Sea. The only remnant of a powerful tsunami visible in the landscape of the area is currently the very large and shallow Gardno Lake, which was previously regarded as a bay of the Baltic Sea from the Holocene transgression period.

\section{CONCLUSIONS}

The research into the Holocene deposits found at Rowy (on the central coast of Poland) showed evidence that during the Middle Holocene $(6,615 \pm 130 \mathrm{cal}$. yr BP), a tsunami event occurred on the southern coast of the Baltic Sea. This has been recorded as a thick (up to $3 \mathrm{~m}$ ) layer of marine sand that is rich in marine shells, rip-up clasts of peat, silt and tree branches and trunks (Pinus sp.). Their presence is limited to two fossil hemispherical hollows. The causes of the event are unknown; how- 
ever, the hypothesis of a meteorite impact in the coastal zone at Rowy may be considered. The spatial extent of the event is also unknown. Further research is needed to determine whether this event was local in scale. If so, the hypothesis of a meteorite impact will become more likely.

Acknowledgements. The research was supported by a grant from the National Science Center (No. NN 3061267 38). Geophysical expertise were provided by J. Antoniuk and W.
J. Mościcki (AGH University of Science and Technology) and M. Rudzki (Geofizyka Toruń S.A.). J. Michniewicz (Institute of Geology, Adam Mickiewicz University) provided SEM expertise for studying the magnetic grains. The author would like to thank the director of Słowiński National Park, K. Woźniak, for her kind attitude towards the investigations and W. Pawłów for his help during the coring survey. The manuscript was improved greatly by insightful reviews by A. Wysocka and anonymous reviewers, and editorial comments by T.M. Peryt.

\section{REFERENCES}

Abrantes, F., Alt-Epping, U., Lebreiro, S., Voelker, A., Schneider, R., 2008. Sedimentological record of tsunamis on shallow-shelf areas: the case of the $1969 \mathrm{AD}$ and $1755 \mathrm{AD}$ tsunamis on the Portuguese Shelf off Lisbon. Marine Geology, 249: 283-293.

Benson, B.E., Grimm, K.A., Clague, J.J., 1997. Tsunami deposits beneath tidal marshes on northwestern Vancouver Island, British Columbia. Quaternary Research, 48: 192-204.

Blott, S.J., Pye, K., 2001. Gradistat: a grain size distribution and statistics package for analysis of unconsolidated sediments. Earth Surface Processes and Landforms, 26: 1237-1248.

Bogaczewicz-Adamczak, B., Fedorowicz, S., Gołębiewski, R., Miotk, G., 1982. Polodowcowa historia rejonu jeziora Gardno (in Polish). Zeszyty Naukowe Uniwersytetu Gdańskiego, Geografia, 12: 27-49.

Bondevik, S., Lrvholt, F., Harbitz, C., Mangerud, J., Dawson, A.D., Swendsen, J.I., 2005. The Storegga Slide tsunami - comparing field observations with numerical simulations. Marine and Petroleum Geology, 22: 195-208.

Bronk Ramsey, C., Lee, S., 2013. Recent and planned development of the Program OxCal. Radiocarbon, 55: 720-730.

Bryant, E.A., 2008. Tsunami. The Underrated Hazard. Cambridge University Press, New York.

Bryant, E.A., Nott, J., 2001. Geological indicators of large tsunami in Australia. Natural Hazards, 24: 231-249.

Bryant, E.A., Young, R.W., Price, D.M., 1996. Tsunami as a major control on coastal evolution, southeastern Australia. Journal of Coastal Research, 12: 831-840.

Bourgeois, J., 2009. Geological effects and records of tsunamis. In: The Sea, 15: Tsunamis (eds. A.R. Robinson and E.N. Bernard): 53-91. Harvard University Press.

Choowong, M., Murakoshi, N., Hisada, K., Charusiri, P., Charoentitirat, V., Jankaew, K., Kanjanapayont, P., Phantuwongraj, S., 2008. Indian Ocean tsunami inflow and outflow at Phuket, Thailand. Marine Geology, 248: 179-192.

Clague, J.J., Bobrowsky, P.T., 1994a. Evidence for a large earth quake and tsunami 100-400 years ago on western Vancouver Island, British Columbia. Quaternary Research, 41: 176-184.

Clague, J.J., Bobrowsky, P.T., 1994b. Tsunami deposits beneath tidal marshes on Vancouver Island, British Columbia. GSA Bulletin, 106: 1293-1303.

Clague, J.J., Bobrowski, P.T., Hamilton, T.S., 1994. A sand sheet deposited by tsunami at Port Alberni, British Columbia. Estuarine and Coastal Shelf Science, 38: 413-421.

Clague, J.J., Bobrowsky, P.T., Hutchinson, I., 2000. A review of geological records of large tsunamis at Vancouver Island, British Columbia, and implications for hazard. Quaternary Science Reviews, 19: 849-863.

Dawson, A.G., 1994. Geomorphological effects of tsunami run-up and backwash. Geomorphology, 10: 83-94.

Dawson, A.G., Shi, S.Z., 2000. Tsunami deposits. Pure and Applied Geophysics, 157: 875-897.

Dawson, A.G., Stewart, I., 2007. Tsunami deposits in geological record. Sedimentary Geology, 200: 166-183.
Dawson, A.G., Lockett, P., Shi, S., 2004. Tsunami hazards in Europe. Environment International, 304: 577-585.

Dominey-Howes, D., 2002. Documentary and geological records of tsunamis in the Aegean Sea region of Greece and their potential value to risk assessment and disaster management. Natural Hazards, 25: 195-224.

Dominey-Howes, D., 2007. Geological and historical records of tsunami in Australia. Marine Geology, 239: 99-123.

Dominey-Howes, D., Humphreys, G.S., Hesse, P.P., 2006. Tsunami and paleotsunami depositional signatures and their potential value in understanding the late Holocene tsunami record. The Holocene, 16: 1095-1107.

Engel, M., Brückner, H., 2011. The identification of palaeo-tsunami deposits - a major challenge in coastal sedimentary research. Coastline Reports, 17: 65-80.

Friedman, G.M., 1961. Distinction between dune, beach and river sands from their textural characteristics. Journal of Sedimentary Petrology, 31: 541-592.

Friedman, G.M., 1967. Dynamic processes and statistical parameters compared for size frequency distribution of beach and river Journal of Sedimentary Petrology, 37: 327-354.

Friedman, G.M., 1979. Differences in size distributions of populations of particles among sands of various origins. Sedimentology, 26: 859-862.

Fujino, S., Naruse, H., Suphawajruksakul, A., Jarupongsakul, T., Murayama, M., Ichihara, T., 2008. Thickness and grain-size distribution of Indian Ocean tsunami deposits at Khao Lak and Phra Thong Island, southwesten Thailand. In: Tsunamites Features and Implications (eds. T. Shiki, Y. Tsuji, T. Yamazaki and K. Minoura): 123-132. Elsevier B.V., Amsterdam.

Fujiwara, O., Masuda, F., Sakai, T., Irizuki, T., Fuse, K., 2000. Tsunami deposits in Holocene bay mud in southern Kanto region, $\mathrm{Pa}$ cific coast of central Japan. Sedimentary Geology, 135: 219-230.

Gelfenbaum, G., Jaffe, B.E., 2003. Erosion and sedimentation from 17 July, 1998 Papua New Guinea tsunami. Pure and Applied Geophysics, 160: 1969-1999.

Goff, J.R., Rouse, H.L., Jones, S.L., Hayward, B.W., Cochran, U., McLea, W., Dickinson, W.W., Morley, M.S., 2000. Evidence for an earthquake and tsunami about $3100-3400 \mathrm{yr}$ ago, and other catastrophic saltwater inundation recorded in a coastal lagoon, New Zealand. Marine Geology, 170: 231-249.

Goff, J., Chagué-Goff, C., Nichol, S., 2001. Paleotsunami deposits: a New Zealand perspective. Sedimentary Geology, 143: 1-6.

Goff, J., Dudley, W.C., de Maintenon, M.J., Cain, G., Coney, J.P., 2006. The largest local tsunami in 20th century Hawaii. Marine Geology, 226: 65-79.

Goff, J., Pearce, S., Nichol, S.L., Chagué-Goff, C., Horrocks, M. Strotz, L., 2010. Multi-proxy records of regionally-sourced tsunamis, New Zealand. Geomorphology, 118: 369-382.

Goff, J., Terry, J.P., Chagué-Goff, C., Goto, K., 2014. What is a mega-tsunami? Marine Geology, 358: 12-17.

Haines, P.W., 2005. Impact cratering and distal ejecta: the Australian record. Australian Journal of Earth Science, 52: 481-507.

Hemphill-Haley, E., 1996. Diatoms as an aid in identifying late-Holocene tsunami deposits. The Holocene, 6: 439-448. 
Hills, J.G., Goda, M.P., 1998. Tsunami from asteroid and comet impacts: The vulnerability of Europe. The International Journal of the Tsunami Society, 16: 3-10.

Hindson, R.A., Andrade, C., Dawson, G.A., 1996. Sedimentary processes associated with the tsunami generated by the 1755 Lisbon earthquake on the Algarve coast, Portugal. Physics and Chemistry of the Earth, 21: 57-63.

Hori, K., Kuzumoto, R., Hirouchi, D., Umitsu, M., Janjirawuttikul, N., Patanakong, B., 2007. Horizontal and vertical variation of 2004 Indian tsunami deposits: an example of two transects along the western coast of Thailand. Marine Geology, 239: 163-172.

Hutchison, I., Guilbault, J.-P., Clague, J.J., Bobrowsky, P.T., 2000. Tsunamis and tectonic deformation at the northern Cascadia margin: a 3000-year record from Deserted Lake, Vancouver Island, British Columbia, Canada. The Holocene, 10: 429-439.

Jaffe, B.E., Gelfenbaum, G., 2007. A simple model for calculating tsunami flow speed from tsunami deposits. Sedimentary Geology, 200: 347-361.

Jagnow, B., Gosselck, F., 1987. Bestimmungsschlüssel für die Gehäuseschnecken und Muscheln der Ostsee. Mitteilungen der Zoologischen Museum Berlin, 63: 191-268.

Kijko, A., Skordas, E., Wahlström, R., Mäntyniemi, P., 1993. Maximum likelihood estimation of seismic hazard for Sweden. Natural Hazards, 7: 41-57.

Kokociński, M., Szczuciński, W., Zgrundo, A., Ibragimow, A., 2009. Diatom assemblages in 26 December 2004 tsunami deposits from coastal zone of Thailand as sediment provenance indicators. Polish Journal of Environmental Studies, 18: 93-101.

Kortegas, S., Dawson, A.G., 2007. Distinguishing tsunami and storm deposits: an example from Martinhal, SW Portugal. Sedimentary Geology, 200: 208-221.

Kozarski, S., 1963. Late Glacial disappearance of dead ice in Western Great Poland Lowland (in Polish with English summary). Badania Fizjograficzne nad Polską Zachodnią, 11: 51-60.

Kring, D.A., 1997. Air blast produced by the Meteor Crater impact event and a reconstruction of the affected environment. Meteoritics and Planetary Science, 32: 517-530.

Lowe, D.J., de Lange, W.P., 2000. Volcano-meteorological tsunamis, the c. AD 200 Taupo eruption (New Zeland) and the possibility of a global tsunami. The Holocene, 10: 401-407.

Ložek, V., 1964. Quartärmollusken der Tschechoslowakei. Rozpravy Ustredniho Ustavu Geologickeho, 31: 3-374.

Lutyńska, M., 2008. Phases of development of Lake Gardno based on geochemical and diatomological analysis (in Polish with English summary). In: Holoceńskie przemiany wybrze y i wód południowego Bałtyku - przyczyny, uwarunkowania i skutki, Ogólnopolska Konferencja Naukowa, Smołdzino, 6-9.05.2008 (eds. K. Rotnicki, J. Jasiewicz and M. Woszczyk): 87-100. TEKST, Poznań-Bydgoszcz.

Mamo, B., Strotz, L., Dominey-Howes, D., 2009. Tsunami sediments and their foraminiferal assemblages. Earth-Science Review, 96: 263-278.

Massel, S.R., 2012. Tsunami in coatal zone due to meteorite impact. Coastal Engineering, 66: 40-49.

Moore, G.W., Moore, J.G., 1988. Large-scale bed forms in boulder gravel produced by giant waves in Hawaii. GSA Special Papers, 229: $101-110$.

Moore, A.L., McAdoo, B.G., Ruffman, A., 2007. Landward fining from multiple sources in a sand sheet deposited by the 1929 Grand Banks tsunami, Newfounland. Sedimentary Geology, 200: 336-346.

Morton, R.A., Gelfenbaum, G., Jaffe, B.E., 2007. Physical criteria for distinguishing sandy tsunami and storm deposits using modern examples. Sedimentary Geology, 200: 184-207.

Mörner, N.-A., 1996. Liquefaction and varve deformation as evidence of paleoseismic events and tsunamis. The autumn 14,430 BP case in Sweden. Quaternary Science Review, 15: 939-948.

Mörner, N.-A., 1999. Paleo-tsunamis in Sweden. Physics and Chemistry of the Earth, 24: 443-448.

Mörner, N.-A., 2003. Paleoseismicity of Sweden - a novel paradigm. In: A contribution to INQUA from Sub-Commission no Paleoseismology of the INQUA Commission on Neotectonics, Reno.
Mörner, N.-A., 2004. Active faults and paleoseismicity in Fennoscandia, especially Sweden. Primary structures and secondary effects. Tectonophysics, 380: 139-157.

Mörner, N.-A., 2005. An interpretation and catalogue of palaeoseismicity in Sweden. Tectonophysics, 408: 265-307.

Mörner, N.-A., 2008a. Paleoseismicity and uplift of Sweden. Guidebook, Excursion 11 at 33rd IGC, Oslo.

Mörner, N.-A., 2008b. Tsunami events within the Baltic. Polish Geological Institute Special Papers, 23: 71-76.

Mörner, N.-A., 2011. Paleoseismology: the application of multiple parameters in four case studies in Sweden. Quaternary International, 242: 65-75.

Mörner, N.-A., Dawson, S., 2011. Traces of tsunami events in offand on-shore environments. case studies in the Maldives, Scotland and Sweden. In: The Tsunami Threat: Research and Technology (ed. N.-A. Mörner): 371-388. InTech.

Muszyński, A., Stankowski, W., Pilski, A.S., Kryza, R., Nowak, M., 2012a. Iron meteorite shower in Morasko, Przełązy, Jankowo Dolne. In: The Largest Iron Meteorite Shower in Central Europe (eds. A. Muszyński, R. Kryza, Ł. Karwowski, A.S. Pilski and J. Muszyńska): 27-35. The Bogucki Wydawnictwo Naukowe, Poznań.

Muszyński, A., Pilski, A.S., Muszyńska, J., Kryza, R., Karwowski, Ł., 2012b. Meteorite prospecting and new discoveries in the "Morasko Meteorite" reserve. In: The Largest Iron Meteorite Shower in Central Europe (eds. A. Muszyński, R. Kryza, Ł. Karwowski, A.S. Pilski and J. Muszyńska): 76-81. The Bogucki Wydawnictwo Naukowe, Poznań.

Nanayama, F., Furukawa, R., Shigeno, K., Makino, A., Soeda, Y., Igarashi, Y., 2007. Nine unusually large tsunami deposits from the part 4000 years at Kiritappu marsh along the southern Kuril Trench. Sedimentary Geology, 200: 275-294.

Nemtchinov, I.V., Svetsov, V.V., Kosarev, I.B., Golub, A.P., Popova, O.P., Shuvalov, V.V., 1997. Assessment of kinematic energy of meteoroids detected by satellite-based light sensors. Icarus, 130: 259-274.

Perkins, S., 2009. First a meteorite, then a tsunami: relics of impact, aftermath in Hudson River sediments. Science News, 175: 13.

Peters, R., Jaffe, B., Peterson, C., Gelfenbaum, G., Kelsey, H., 2001. An overview of tsunami deposits along the Cascadian margin. In: Proceedings of the 2001 International Tsunami Symposium: 479-490, Seattle.

Peters, R., Jaffe, B., Gelfenbaum, G., 2007. Distribution and sedimentary characteristics of tsunami deposits along the Cascadian margin of western North America. Sedimentary Geology, 200: 372-386.

Peterson, C.D., Cruikshank, K.M., 2011. Proximal records of paleotsunami runup in Barrage Creek Floodplains from Late-Holocene great earthquakes in the Central Cascadian subduction zone, Oregon, USA. In: Tsunami - a Growing Disaster (ed. M. Mokhatari): 35-58. InTech.

Peterson, C.D., Cruikshank, K.M., Jol, H.M., Schlichting, R.B., 2008. Minimum runup heights of paleotsunami from evidence of sand ridge overtopping at Cannon Beach, Oregon, central Cascadia Margin, U.S.A. Journal of Sedimentary Research, 78: 390-409.

Peterson, C.D., Clague, J.J., Carver, G.A., Cruikshank, K.M., 2013. Recurrence intervals of major paleotsunamis as calibrated by historic tsunami deposits in three localities: Port Alberni, Cannon Beach, and Crescent City, along the Cascadia margin, Canada and USA. Natural Hazards, 66: 321-336.

Piechocki, A., Dyduch-Falinowska, A., 1993. Mięczaki - mał e (in Polish). Polskie Towarzystwo Hydrobiologiczne, PWN, Warszawa.

Piotrowski, A., Szczuciński, W., Sydor, P., Krzymińśka, J., Seidler, J., 2013. Hypothetical tsunami deposits in the Rogowo area, Baltic Sea coast, North Poland. 4th International INQUA Meeting on Paleoseismology, Active Tectonics and Archeoseismology (PATA), 9-14 October 2013. Aachen, Germany.

Raukas, A., Pirrus, R., Rajamåe, R., Tiirmaa, R., 1999. Tracing the age of the catastrophic impact event in sedimentary in sedimentary sequances around the Kaali meteorite craters on the Island of Saaremaa, Estonia. Journal of the European Network of Scientific and Technical Cooperation for the Cultural Heritage, 57: 434-453. 
Raukas, A., Tiirmaa, R., Kaup, E., Kimmel, K., 2001. The age of the llumetsa meteorite craters in southeast Estonia. Meteoritics and Planetary Science, 36: 1507-1514.

Reimer, P.T., Bard, E., Bayliss, A., Beckj, J.W., Blackwell, P.G., Ramsey, C.B., Buck, C.E., Cheng, H., Edwards, R.L., Friedrich, M., Grootes, P.M., Guilderson, T.P., Haflidason, H., Hajdas, I., Hatté, K., Heaton, T.J., Hoffmann, D.L., Hogg, A.G., Hughen, K.A., Kaiser, K.F., Kromer, B., Manning, S.W., Niu, M., Reimer, R.W., Richards, D.A., Scott, E.M., Southon, J.R., Staff, R.A., Turney, C.S.M., van der Plicht, J., 2013 INTCAL13 AND MARINE13 radiocarbon age calibration curves 0-50,000 years cal. BP. Radiocarbon, 55: 1869-1887.

Rotnicki, K., 2001. Stratygrafia i paleogeografia vistulianu Niziny Gardnieńsko-Łebskiej (in Polish). In: Przemiany środowiska geograficznego nizin nadmorskich południowego Bałtyku (ed. K. Rotnicki): 19-29. Bogucki Wydawnictwo Naukowe, Poznań.

Rotnicki, K., 2008. Fossil peat horizons as estimators of former sea level: their present-day ordinates controlled by compaction of underlying lagoon, lake and swamp deposits. In: Holoceńskie przemiany wybrze y i wód południowego Bałtyku - przyczyny, uwarunkowania i skutki (in Polish with English summary). Ogólnopolska Konferencja Naukowa, Smołdzino, 6-9.05.2008 (eds. K. Rotnicki, J. Jasiewicz and M. Woszczyk): 87-100. TEKST, Poznań-Bydgoszcz.

Rotnicki, K., 2009. Identification, age and causes of the Holocene ingressions and regressions of the Baltic on the Polish Middle Coast. Bogucki Wydawnictwo Naukowe, Poznań.

Rotnicki, K., 2010. Geneza jezior przybrze nych Niziny Gardnieńsko-Łebskiej na tle budowy geologicznej i przemian paleogeograficznych obszaru (in Polish). In: POKOS'4 - IV Polska Konferencja Sedymentologiczna, Smołdzino, 21-26.06.2010 (eds. J. Rotnicka, W. Szczuciński, K. Skolasińska, R. Jagodziński and J. Jasiewicz): 154-62. Bogucki Wydawnictwo Naukowe, Poznań.

Rotnicki, K., Borówka, R.K., 1995. The last cold period in the Gardno-Łeba Coastal Plain. Journal of Coastal Research, Special Issue, 22: 225-229.

Rotnicki, K., Młynarczyk, Z., Szczot, S., 1999a. „MERES” - small-gabarit equipment for not deep geological borings (in Polish with English summary). In: Ewolucja geosystemów nadmorskich Południowego Bałtyku (eds. R.K. Borówka, Z. Młynarczyk and A. Wojciechowski): 161-168. Bogucki Wydawnictwo Naukowe, Poznań-Szczecin.

Rotnicki, K., Borówka, R.K., Pazdur, A., Hałas, S., Krzymińska, J., Witkowski, A., 1999b. Main phases of the Southern Baltic transgression on the Polish Middle Coast during the Holocene. Quaternary Studies in Poland, 16: 67-79.

Rotnicki, K., Czerniawska, J., Muszyński, A., Michalik, M., 2008. Fossil hollows at Rowy (Gardno-Łeba Coastal Plain, Polish Middle Coast): evidence of extreme storm surge or meteorite impact in the Middle Holocene - results of the preliminary study. In: International Conference on Environmental Impact of Tsunami, Book of Abstracts, September 25-28, 2008, Słubice-Poznań (eds. S. Lorenc and W. Szczuciński): 92-93. Adam Mickiewicz University and The Coordinating Committee for Geoscience Programmes in East and Southeast Asia (CCOP).

Rotnicki, K., Alexandrowicz, S.W., Pazdur, A., Goslar, T., Borówka, R.K., 2009a. Stages of the formation of the Łeba barrier-lagoon system on the basis of the geological cross-section near Rąbka (southern Baltic coast, Poland). Studia Quaternaria, 26: 3-24.

Rotnicki, K., Czerniawska, J., Lutyńska, M., Muszyński, A., Michalik, M., 2009b. Fossil hollows without outlets at Rowy (Gardno-Łeba Coastal Plain, Polish Middle Coast) remnants of late glacial dead ice, evidence of extreme storm surge or a meteorite impact in the Middle Holocene - results of preliminary study (in Polish with English abstract). Geography Series, 88: 467-492.

Scheffers, A., Kelletat, D., 2003. Sedimentologic and geomorphologic tsunami imprints worldwide - a review. Earth-Science Review, 63: 83-92.

Schlichting, R.B., Peterson, C.D., 2006. Mapped overland distance of paleotsunami high-velocity inundation in back-barrier wetlands of the Central Cascadia Margin, U.S.A. Journal of Geology, 114: 577-592.

Shoemaker, E.M., MacDonald, F.A., Shoemaker, C.S., 2005. Geology of five small Australian impact craters. Australian Journal of Earth Sciences, 52: 529-544

Skompski, S., 1991. Fauna czwartorzędowa Polski. Bezkręgowce (in Polish). Wydawnictwo Uniwersytetu Warszawskiego.

Smith, D.E., Foster, I.D.L., Long, D., Shi, S., 2007. Reconstructing the pattern and depth of flow onshore in a palaeotsunami from associated deposits. Sedimentary Geology, 200: 362-371.

Smoot, J.P., Litwin, R.J., Bischoff, J.L., Lund, S.J., 2000. Sedimentary record of the 1872 earthquake "Tsunami" at Owens Lake, southeast California. Sedimentary Geology, 135: 241-254.

Stankowski, W., 2010. Morasko Metorite. Geology Series, 19. Adam Mickiewicz University, Poznań.

Stankowski, W.T.J., Katrusiak, A., Budzianowskil, A., 2006. Crystallographic variety of magnetic spherules from Pleistocene and Holocene sediments in the northern foreland of Morasko-Meteorite Reserve. Planetary Space Science, 54: 60-70.

Szczuciński, W., 2008. Potential geological and environmental impacts of tsunami waves on the coastal zone of Baltic Sea (in Polish with English summary). In: Holoceńskie przemiany wybrze y i wód południowego Bałtyku - przyczyny uwarunkowań i skutki (eds. K. Rotnicki, J. Jasiewicz and M. Woszczyk): 119-125. Poznań-Bydgoszcz.

Uścinowicz, S., 2003. Relative sea-level changes, glacio-isostatic rebound and shoreline displacement in the southern Baltic. Polish Geological Institute Special Papers, 10: 1-79.

Uścinowicz, S., 2006. A relative sea-level curve for the Polish Southern Baltic Sea. Quaternary International, 145-146: 86-105.

Vött, A., Brückner, H., Brockmüller, S., Handl, M., May, S.M., Gaki-Papanastassiou, K., Herd, R., Lang, F., Maroukian, H., Nelle, O., Papanastassiou, D., 2009. Traces of Holocene tsunamis across the Sound of Lefkada, NW Greece. Global Planetary Change, 66: 112-128.

Witter, R.C., 1999. Late Holocene paleosesmicity, tsunami and relative sea-level changes along the south-central Cascadia subduction zone, southern Oregon, U.S.A. Ph.D thesis, University of Oregon.

Wojciechowski, A., 1990. Lithofacies analysis of Gardno Lake deposits (in Polish with English summary). Seria Geografia, 49. Adam Mickiewicz University, Poznań.

Wojciechowski, A., 2000. Palaeohydrological changes in the central Wielkopolska Lowland during the last 12,000 years on the basis of deposits of the Kórnik-Zaniemyśl Lakes (in Polish with English summary). Seria Geografia, 63. Wyd. Naukowe UAM, Poznań.

Young, R.W., Bryant, E.A., 1992. Catastrophic wave erosion on the southeastern coast of Australia: impact of the Lanai tsunamis ca. 105 ka. Geology, 20: 199-202.

Wünnemann, K., Weiss, R., 2015. The meteorite impact-induced tsunami hazard. Philosophical Transactions of the Royal Society A, 373: 20140381.

mudziński, L., 1982. Zoobentos litoralu Bałtyku (in Polish). In Zoobentos Bałtyku lat sześćdziesiatych (ed. L. mudziński and J. Ostrowski): 126-133. Wyd. Wy szej Szkoły Pedagogicznej, Stupsk. 